\title{
Inheritance of glabrous plants in Helianthemum oelandicum var. oelandicum and spatial patterns of allele frequencies in local populations
}

\author{
Björn Widén ${ }^{1}$ (1)
}

Received: 12 February 2018 / Accepted: 23 August 2018 / Published online: 7 September 2018

(c) The Author(s) 2018

\begin{abstract}
Helianthemum oelandicum var. oelandicum is an endemic taxon on the Baltic island of Öland, SE Sweden. Plants can be classified into two morphs: the bristled morph (with bristles and with or without scattered stellate hairs) and the glabrous morph (without bristles and stellate hairs). In crosses between plants assumed to be homozygous for the trait that characterises the phenotypes of the two morphs, offspring in F1 could not be distinguished from the bristled morph. Segregation in F2 did not deviate from the expected 3:1 ratio (bristled morphs/glabrous morphs), indicating one major gene with a dominant allele for the phenotype of the bristled morph and a recessive allele for the phenotype of the glabrous morph. Besides the Mendelian inheritance of presence/absence of hairs, the density of hairs appeared to be further modified by quantitative genes. The frequency of the recessive allele for the phenotype of the glabrous morph varied among local populations and showed a geographical structure, both on local and regional scales. Possible mechanisms behind the spatial variation in indumentum are discussed.
\end{abstract}

Keywords Allele frequency $\cdot$ Helianthemum $\cdot$ Major gene $\cdot$ Mendelian inheritance $\cdot$ Natural population $\cdot$ Periodical inundation $\cdot$ Pubescence $\cdot$ Topography

\section{Introduction}

Helianthemum is a young genus (Guzmán and Vargas 2009; Aparicio et al. 2017) with several variable species complexes (Widén 2015, 2017). Recent phylogenetic studies (Aparicio et al. 2017) have indicated a burst of Plio-Pleistocene diversification of the genus coinciding with the Messinian Salinity Crisis, the onset of a Mediterranean climate and the Quaternary glaciations (Suc 1984; Hewitt 2000; Fiz-Palacios and Valcárcel 2013). Three well-supported clades contained branches with unresolved polytomies towards the tip of the

Handling Editor: Andreas Tribsch.

Electronic supplementary material The online version of this article (https://doi.org/10.1007/s00606-018-1541-0) contains supplementary material, which is available to authorized users.

Björn Widén

bjorn.widen@biol.lu.se

1 Department of Biology, Section Biodiversity, Lund University, Sölvegatan 37, 22332 Lund, Sweden consensus trees, which were ascribed to rapid speciation and reticulate evolution in the Pleistocene (Aparicio et al. 2017).

Common to many of the species complexes is an intricate differentiation in pubescence (Janchen 1907; Proctor and Heywood 1968). The most frequent kinds of hairs found in Helianthemum are bristles, stellate hairs and glandular hairs on leaf, peduncle and calyx (Grosser 1903). The presence or absence of hairs on different parts of the plant has been used as diagnostic characters in the taxonomy of many species groups (Janchen 1907; Proctor and Heywood 1968).

One of the most important diagnostic characters is the presence or absence of a dense cover of stellate hairs on the abaxial surface of the leaves. Widén $(2015,2017)$ has recently shown that the density of stellate hairs on the abaxial surface of the leaves is determined by quantitative genes and that the threshold density of stellate hairs used as a key character is governed by a recessive allele of a Mendelian gene in two species, $H$. nummularium (L.) Mill. and $H$. oelandicum (L.) Dum.Cours., belonging to different welldefined sections of the genus (cf. Aparicio et al. 2017).

Helianthemum nummularium and $H$. oelandicum are the two most widespread species in the genus and are both 
distributed from lowland to high alpine habitats. They show parallel trends in diversification of hairs, and both have centres of diversity in and around areas that have gone through cycles of glaciations (Janchen 1907; Proctor and Heywood 1968; Svendsen et al. 2004; Soubani et al. 2014; Volkova et al. 2016). Based on the similar inheritance of a key character, stellate hairs on the abaxial surface of the leaves, Widén (2017) suggested that natural selection acting on pubescence has moulded parallel adaptation in the two species (cf. Wood et al. 2005). Besides the common key character-a whitish cover of stellate hairs on the abaxial surface of the leaves-both species have developed morphs with glabrous or almost glabrous leaves in alpine habitats: $H$. nummularium subsp. glabrum (Koch) Wilczek and morphs of H. oelandicum subsp. alpestre (Jacq.) Breistr, respectively. Both species have also developed especially hairy morphs in alpine habitats: $H$. nummularium subsp. tomentosum (Scop.) Schinz. \& Thell. and morphs of H. oelandicum subsp. incanum (Willk.) G.López (cf. Janchen 1907, 1909). To understand the evolutionary mechanisms behind the rapid radiation in the Pleistocene (Aparicio et al. 2017), a closer examination of local differentiation of pubescence is motivated in an area where the timeframe of differentiation can be established.

Helianthemum oelandicum has been divided into several taxa in Europe, North Africa and the Caucasus (Janchen 1907; Proctor and Heywood 1968; Widén 2010). In addition to hairs, the most important diagnostic characters used to circumscribe taxa in the complex are size/shape of leaves, size of flowers and flowering phenology (Proctor and Heywood 1968; Widen 2017). The H. oelandicum complex is represented by the endemic subspecies oelandicum, with two varieties in a very restricted geographical area (about $1350 \mathrm{~km}^{2}$ ) on the Baltic island of Öland (Fig. 1, Widén 2010). The subspecies oelandicum on Öland is important for understanding the evolution of traits in the complex, since its morphological variation covers most of the whole range of variation found in the main diagnostic characters in the rest of the complex.

Helianthemum oelandicum subsp. oelandicum var. oelandicum can be identified by a short period of concentrated flowering (CF) in early summer and the lack of a dense cover of stellate hairs on the abaxial surface of the leaves (with or without bristles), while $H$. oelandicum subsp. oelandicum var. canescens (Hartm.) Fr. consists of plants with protracted flowering (PF) during the summer and with or without a dense cover of stellate hairs on the abaxial surface of the leaves (but always with bristles). The two varieties have allopatric distributions (Widén 2010) in the area of steppe-like 'alvar' grasslands on Öland; var. oelandicum is common in suitable habitats throughout the island except for the area of var. canescens in the southernmost part of the island (Fig. 1).

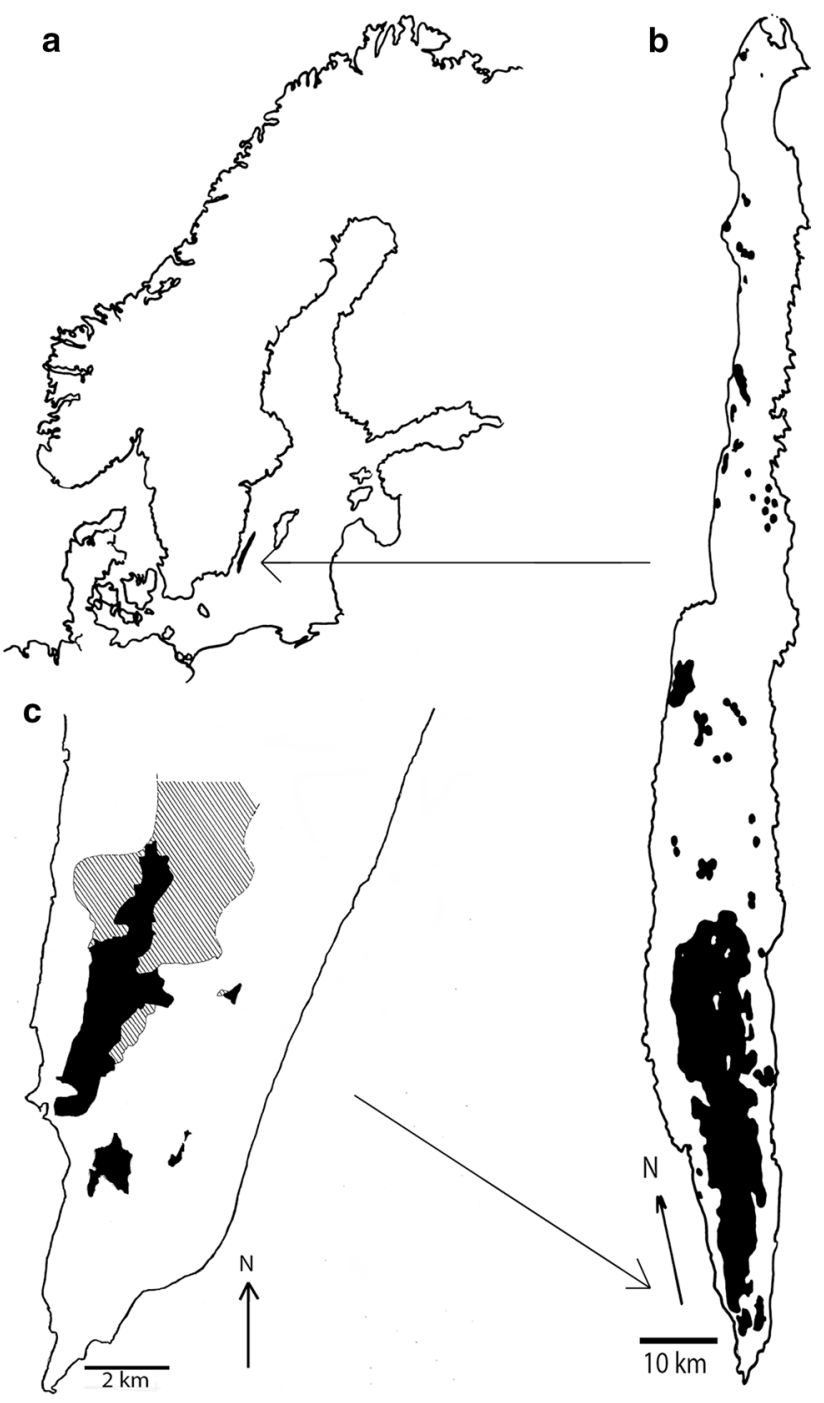

Fig. 1 a The Baltic area. b The distribution of $H$. oelandicum (black) on the Baltic island of Öland (Sterner 1936b). The Great Alvar coincides with the continuous distribution of $H$. oelandicum on the third half of Öland. c The distribution of $H$. oelandicum on the southernmost part of Öland. Black indicates the area where $>90 \%$ of the plants belong to var. canescens and stripes indicate the distribution of var. oelandicum. The area marked with black in the southernmost part of Öland represents the outer border of several small more or less isolated patches of var. canescens

Widén (1988) described, in detail, variation in the density of hairs and the correlation between types of hairs in different parts of the plant. Density of hairs showed a continuous variation from glabrous plants in var. oelandicum to plants with a whitish cover of stellate hairs on the abaxial surface of leaves in var. canescens. Both varieties on Öland demonstrated a significant geographical structure in pubescence that, according to Widén $(1980,1988,2010,2017)$, reflects the heterogeneity of habitats in the grasslands; hairy plants were more frequent in dry, well-drained habitats, whereas 
less hairy plants were more common in poorly drained, periodically inundated habitats with freezing and thawing during winter (cf. Sterner 1936a).

The morphological diversity and geographical distribution of morphs on Öland, covered by the ice during LGM (Svendsen et al. 2004), have developed over a period of approximately 10,000 years (Königsson 1968). This is in sharp contrast to the diversity in the rest of the complex, which has a more complicated glacial and postglacial history starting in the early Pleistocene (Svendsen et al. 2004). $H$. oelandicum subsp. oelandicum on Öland is therefore a suitable model for studies of the mechanism governing character evolution of the whole $H$. oelandicum complex, as well as the Pleistocene radiation of several species complexes in Helianthemum in general (Aparicio et al. 2017).

The present study is the third in a series examining the genetics behind variation in pubescence of Helianthemum (cf. Widén 2015, 2017). Here, I report on (1) the result of a crossing programme to unravel the genetics of hairlessness in H. oelandicum var. oelandicum. I also (2) translate this character into allele frequencies in natural populations of $H$. oelandicum var. oelandicum and show the geographical pattern in allele frequencies both at regional (3) and local (4) scales, based on data in Widén (1988). Allele frequencies in natural populations will be used in further studies of adaptation of $H$. oelandicum to the specific environmental conditions on Öland (B. Widén unpublished data).

\section{Materials and methods}

\section{The study area}

The geology of the Baltic island of Öland, SE Sweden, comprises Cambrian and Ordovician bedrock covered by Quaternary deposits (Königsson 1968). The island was covered by the ice during LGM (Björck 1995; Svendsen et al. 2004). As the ice retreated, $H$. oelandicum was an early immigrant (Berglund 1966; Königsson 1968; Iversen 1973; Mortensen et al. 2011), reaching Öland via south-western and southeastern migration routes (Soubani 2010). Pollen diagrams indicate that $H$. oelandicum was abundant in the open landscape of the early postglacial period, but declined during a climate regression in the Atlantic period when the area of forest increased. The Neolithic human impact opened up the landscape again, which was reflected in increasing frequencies of Helianthemum pollen (Königsson 1968).

The Great Alvar in the southern third of the island (Fig. 1b) is a $255-\mathrm{km}^{2}$ horizontal plateau of Ordovician bedrock with soil-filled fissure systems and shallow ridges of glaciofluvial deposits moulded by wave action along the shores at different stages of the postglacial Baltic Sea. The term 'alvar' refers to calcareous grasslands on thin soils (often less than $20 \mathrm{~cm}$ ) on Ordovician or Silurian limestone that are naturally open (Ekstam and Forshed 2002; Reitalu et al. 2014). The surface of the Great Alvar slopes gently towards ESE and the north-south ridges of glaciofluvial deposits often dam the surface water, creating temporary pools or wet meadows (Königsson 1968). A mosaic of dry grassland vegetation types has developed on the Great Alvar depending on local drainage conditions and soil types; from acid sand and gravel to base-rich, thin weathered soils directly on the fissured limestone bedrock (Albertsson 1950; Rosén 1982; Krahulec et al. 1986; Bengtsson et al. 1988).

Helianthemum oelandicum often occurs in large, virtually continuous populations (Fig. 2a). It is one of the dominant species on the Great Alvar (Fig. 2a, b) and in some scattered alvar areas with weathered soils directly on the bedrock in middle and northern Öland (Fig. 1; Sterner 1936b).

The island of Öland is situated in the rain shadow of the Swedish mainland, and annual precipitation is less than $500 \mathrm{~mm}$. The relatively low and unpredictable summer precipitation and the high number of sunshine hours often create drought during summer (Fig. 2c; cf. Widén 1980; Rosén 1982). Heavy rains in autumn combined with snowmelt often saturate the weathered soils, causing flooding of the vegetation and considerable frost disturbance during winter and spring (Fig. 2d, e).

\section{The model system}

Widén (1988) classified and quantified hairs on leaf, peduncle and calyx of $H$. oelandicum on Öland. Variation in density of hairs (stellate hairs, bristles and glandular hairs, separately) was classified into seven scores from 0 (no hairs) to 3 (densely covered with hairs) for each trait (except for glandular hairs and for bristles on sepals) using templates to obtain accurate and repeatable measures of pubescence (cf. Widén 2015, 2017). Widén (1988) used the sum of hair scores of individual plants as a hair index to describe the patterns of diversity of hairy plants on Öland, with a higher hair index for $H$. oelandicum var. canescens than for $H$. oelandicum var. oelandicum. The individual hair score for the density of stellate hairs on the abaxial surface of the leaves was used to analyse the genetics of hairs in Widén $(2015,2017)$.

In this study, I focus on bristles on leaves (3rd to 5 th leaves on the shoot), but I also report on stellate hairs on the abaxial surface of the leaves. Each plant was classified according to the hair scores described in Widén (1988). To distinguish between bristles and stellate hairs on leaves, I denote the scores as hair ${ }_{(\text {brl) }}$ and hair (stab) $_{\text {(bristles on leaves }}$ and stellate hairs on the abaxial surface of the leaves, respectively) in this report. Hair $_{\text {(stab) }}$ scores were recently described and illustrated under the name of hair scores in Widén $(2015,2017)$. 

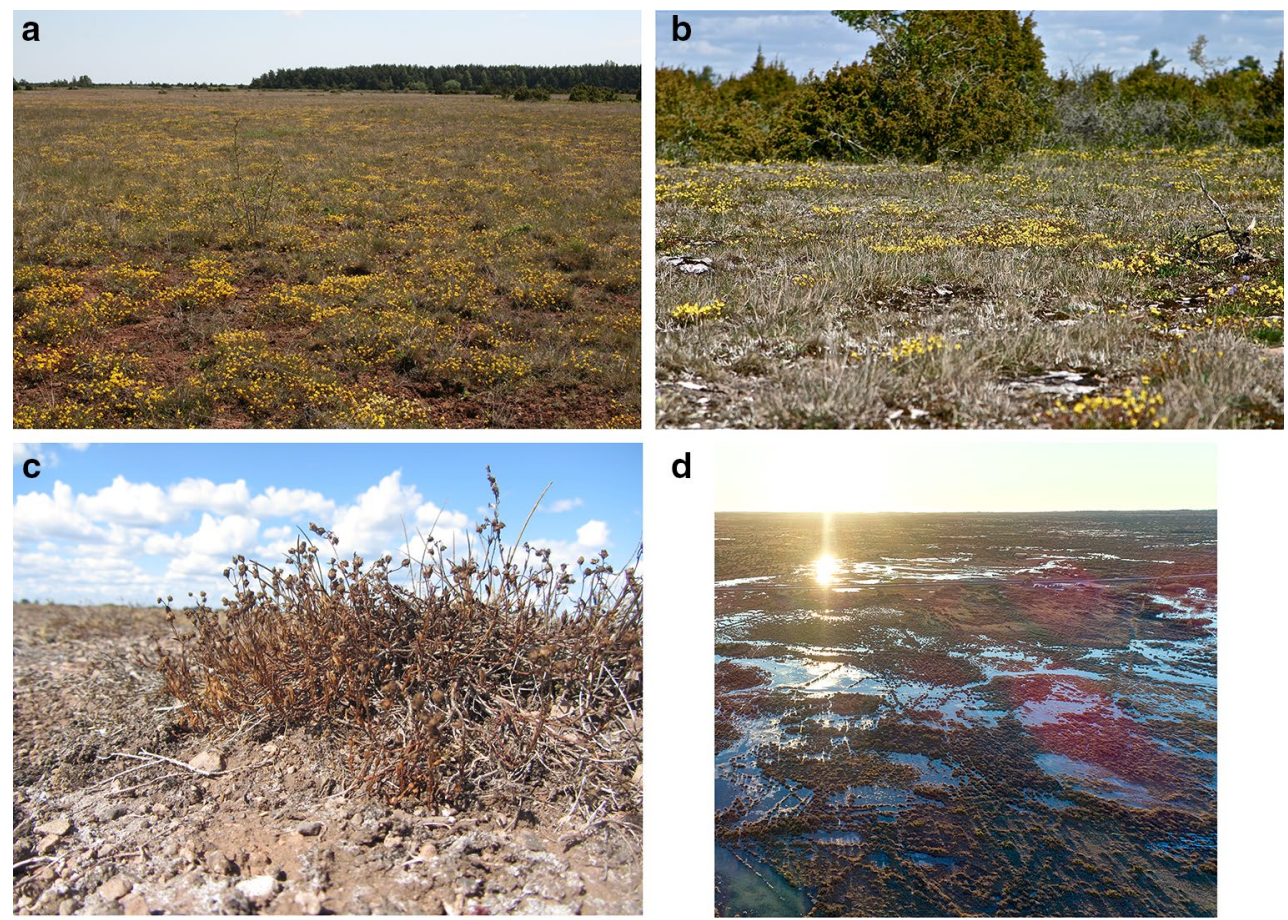

d
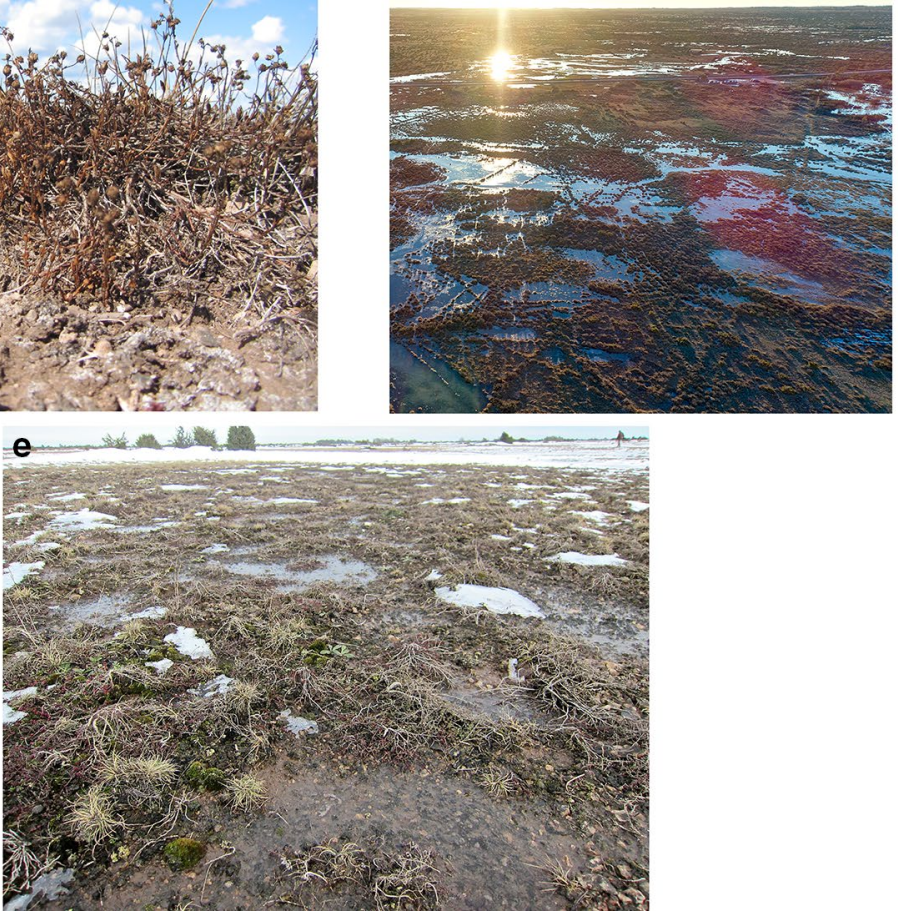

Fig. 2 a Helianthemum oelandicum is the dominating species over large areas of the Great Alvar. This view is taken eastwards from a point SE of the local population 36 (Vickleby Alvar, cf. Fig 5) in an area dominated by glabrous plants and close to the area shown in Fig. 2e, 13 June 2010. Photograph: E. Rosén. b Helianthemum oelandicum often occurs in species-rich communities in well-drained habitats (glaciofluvial deposits and soil-filled cracks in the limestone pavement). This photograph is taken north of the pine plantation shown at the horizon in Fig. 2a, 2 June 2006. Photograph: M. Widén. c Drought has an impact on different life cycle stages of $H$. oelandicum. Early drought in spring may reduce reproductive success of individual plants, and long-lasting summer drought often kill plants

Using a template, the criteria for the hair $\mathrm{brrl}_{\text {s }}$ scores were as follows: $0=$ no bristles; $1=$ bristles only on the petiole and sparsely on the midrib on the abaxial surface of the leaf; $2=$ bristles on petiole, midrib, leaf margin and scattered on the adaxial surface of the leaf; $3=$ bristles as in (2), but with a dense cover on the adaxial surface of the leaf (Figs. 3 and 4). Because of the almost continuous variation in density of hairs, examined specimens often fell between two categories over large areas. Photograph taken on 4 August 2018. d Aerial view of the Great Alvar of the Baltic island of Öland, west of Möckelmossen showing the mosaic of standing water after heavy rain (photograph taken at an altitude of $70 \mathrm{~m}$ above sea level, 7 January 2018, by T. Gunnarsson, with permission from Lantmäteriet Dnr. 6012018/396). e Vickleby Alvar after snow melting 19 March 2018. The substrate is a thin layer of weathered soil $(<10 \mathrm{~cm})$ on the horizontal, \pm impermeable limestone pavement. The extensive root system of $H$. oelandicum penetrates narrow fissures in the bedrock and anchors the plant even during heavy frost heaving. Vegetation is poor in vascular plant species but rather species-rich in cryptogams. Photograph: M. Widén

in the template, so individual specimens were given one of the seven scores $0,0.5,1,1.5,2,2.5$ or 3 . The hair scores were determined using a dissecting microscope in the laboratory or with a hand lens in the field (in the field, a simplified scale was used: 0, 1, 2 and 3).

Because of the risk of subjectivity in the classification, I tested the stability of the scores by classifying the hairs more than once on the same specimen in all local populations 

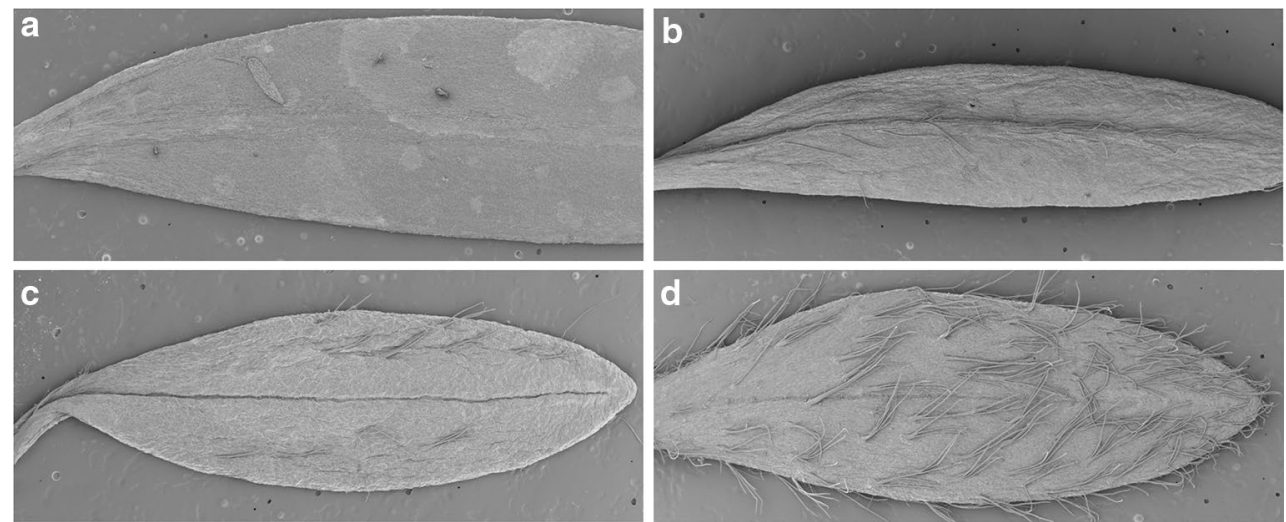

Fig. 3 SEM photographs of leaves with bristles in Helianthemum oelandicum. a, b Abaxial surface of leaves of $H$. oelandicum var. oelandicum.

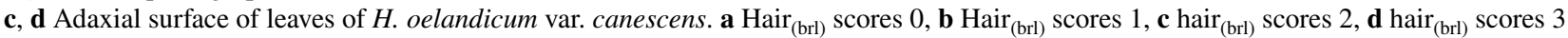
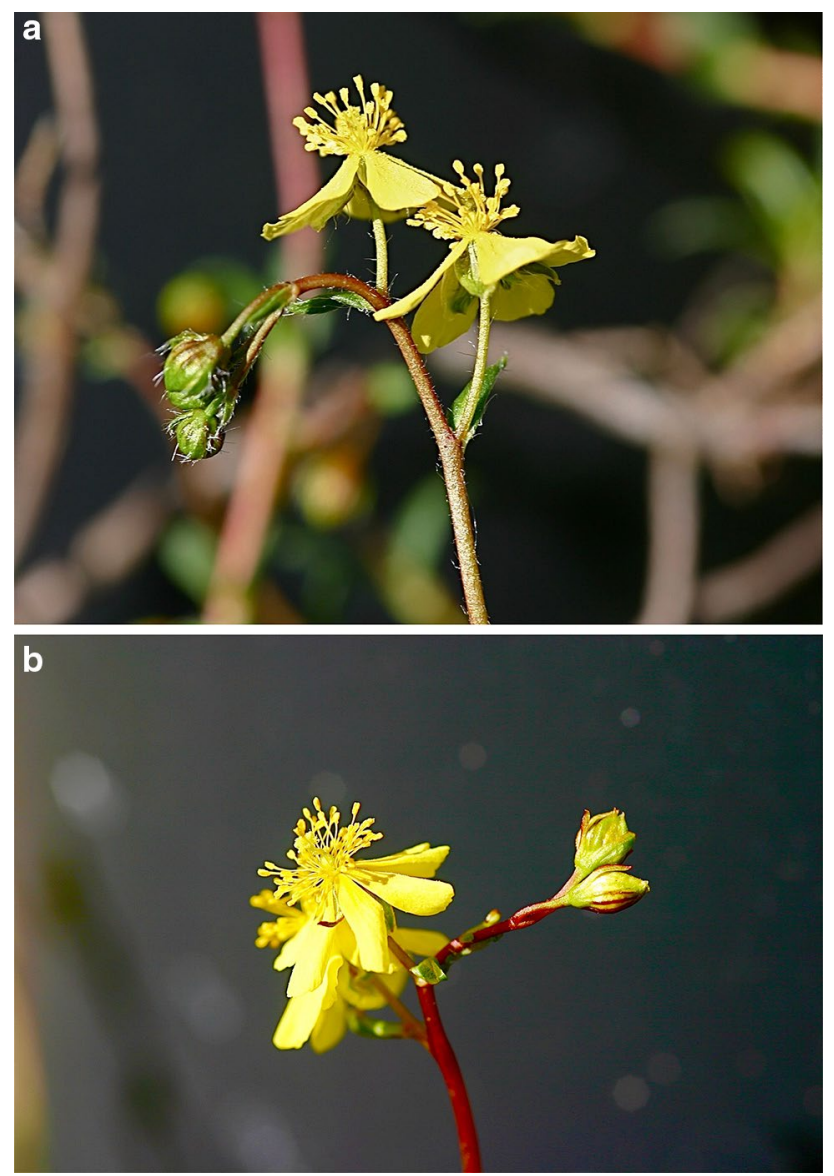

Fig. 4 The density of hairs in different parts of Helianthemum oelandicum is usually strongly correlated, here illustrated with inflorescences of var. oelandicum. a Bristles on calyx, peduncle and leaves with hair $_{(\mathrm{brl})}$ score 1. b Calyx, peduncle and leaves with hair ${ }_{(\mathrm{brl})}$ score 0

in field sample 3 ( $n=16$, see below); (1) a well-developed branch of each specimen was first classified and (2) an alternative branch was classified twice on different occasions. The specimens were given a random code number to prevent my knowledge of their population identity causing bias in my classification. Comparison of two classifications of the same branch is a test of the repeatability of the method, and comparing (1) and (2) gives information of the degree of variation within plants.

\section{Sampling design for population survey}

The study system was established in the early 1970s, and the sampling of plants was performed in three steps (described in more detail in Widén 1980, 1988, 2017). Firstly, sites $(100 \times 100 \mathrm{~m})$ were selected to cover the full distribution area of $H$. oelandicum var. oelandicum on Öland (Figs. 1 and 5). These sites are considered as local populations. Secondly, one or three squares $(10 \times 10 \mathrm{~m})$ were located within each site (in 1973-1975). Thirdly, within each square, a number of selected plots $(1 \times 1 \mathrm{~m})$ were used to sample adult plants (flowering plants). The samples were taken at random by determining the coordinates of the NW corners of squares and plots from a list of random digits.

Four types of samples were used for the morphometric analysis. Field sample 1: from each plant $(n=20)$ in one $10 \times 10 \mathrm{~m}$ square in all sites ( $n=106$, Fig. 5), a branch with a leaf rosette and inflorescences was preserved in FAA. In a few cases, a larger part of the plant was dried and pressed. A preliminary survey of the morphological variation in field sample 1 indicated great variation in pubescence among local populations. In order to establish if field sample 1 reflected variation in hairs within the local population, representative sites $(n=16)$ were selected for sampling additional squares $(10 \times 10 \mathrm{~m})$. Field sample 2: 20 plants from one square were preserved in FAA. Field sample 3: 20 plants from another square within the site were preserved as dried and pressed material (whole plants or a part of large plants). 


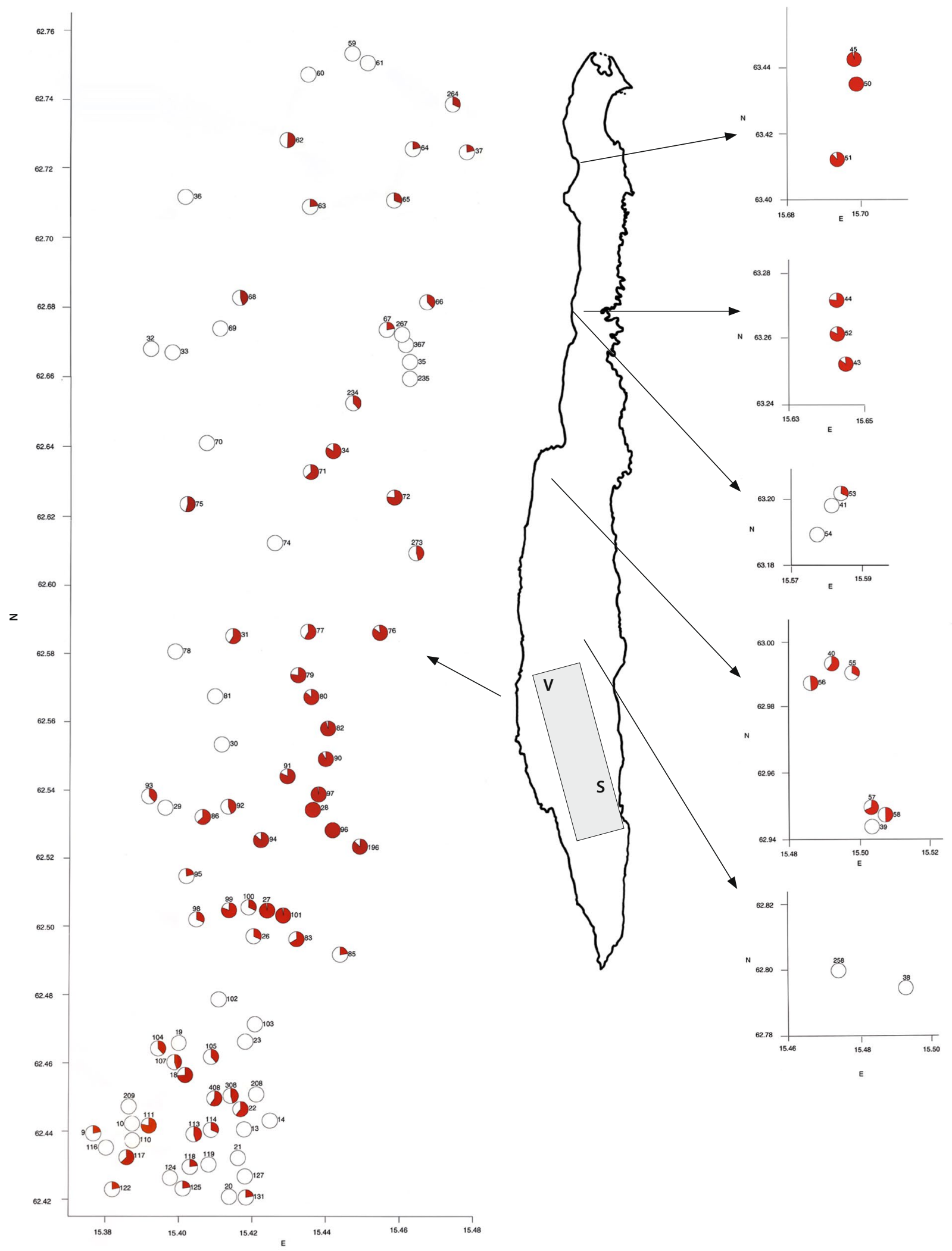

Fig. 5 The distribution of sites in field sample 1 of Helianthemum oelandicum var. oelandicum. Allele frequencies in local populations are indicated by the pie charts; the frequencies of the recessive glab allele for glabrous plants are shown by red; population identity next to the diagram, the $x$ - and $y$-axes show the coordinate in the Swedish Grid (RT90) $\times 10^{-5}$. The location of transects is shown on the map of Öland; V = Vickleby alvar, $\mathrm{S}=$ Sandåsen region 
Common garden sample: a branch of each of up to 20 plants per local population $(n=10)$ raised in a common garden at Lund University was preserved in FAA. The plants were derived from seeds collected in permanent plots in field sample 1 (for further details, see Widén 2017).

\section{Sampling design for studies of local population differentiation}

Two regions were selected for detailed mapping of local population structure and spatial distribution of plants with different hair scores (see Fig. 5). These alvar areas represented the habitats occupied by $\mathrm{H}$. oelandicum in terms of drainage; from well-drained glaciofluvial deposits or virtually bare limestone bedrock with wide, soil-filled cracks to flat, periodically inundated, weathered soil directly on the bedrock (Fig. 2a, b). The presence or absence of $H$. oelandicum was recorded within a radius of $10 \mathrm{~m}$ at each $50-\mathrm{m}$ point along transects extending from the edge of the alvar, perpendicular to the north-south ridges of glaciofluvial deposits on the Great Alvar. The orientation of a W-E transect was determined with a compass, and a 50-m measuring-tape was fixed between two observation points.

If the density of $H$. oelandicum was at least five mature plants per $\mathrm{m}^{2}$, the number of mature plants (flowering/ fruiting) and hair scores of five plants in one or two $1-\mathrm{m}^{2}$ plots was recorded (cf. Widén 1988). The frequency of $H$. oelandicum at each 50-m interval along a transect or part of a transect was used as a rough measure of the population structure; the higher the figure, the more continuous was the population. Habitat characteristics, such as topography, soil type and vegetation (Albertsson 1950), were estimated and recorded using a tape recorder according to a standardised protocol at each 50-m interval with $\mathrm{H}$. oelandicum (referred to in the text as plots) (cf. Widén 1980, 1988). These estimates were all different aspects of drainage and showed significant correlations (Widén 1988). Here, I only use the estimation of topography by giving each plot a value from 1 to 4 where 1 means low ridges of glaciofluvial deposits and 4 means an even alvar plain without depressions in the bedrock (see Widén 1988 for more details).

\section{Vickleby alvar (Fig. 5)}

This region was selected to reveal the mosaic of Helianthemum populations in relation to the damming effect of the north-south glaciofluvial ridges on the Great Alvar. The alvar area SE of the village Vickleby has two larger wetlands with moist grassland communities or temporary pools in shallow depressions in the bedrock or dammed by low glaciofluvial ridges: Nedre Lindskärr (NL), approximately $0.5 \mathrm{~km}$ east of the alvar edge, and Övre Lindskärr, approximately $1 \mathrm{~km}$ east of the alvar edge. The ridges and accompanying wetlands create gradients of vegetation types with a north-south distribution. Measurements were taken in mid-July 1975, a dry summer without surface water in the two wetlands.

Three W-E transects were made from the western edge of the alvar starting at site 36 (Fig. 5), just west of NL. The transects were approximately $200 \mathrm{~m}$ apart. H. oelandicum was recorded in two independently selected plots at each 50-m interval along the transects, by first recording one plot when moving from west to east and then recording another plot on the way back.

\section{Storåsen region (Fig. 5)}

This region was selected to illustrate the differences between western and eastern parts of the Great Alvar north of the villages Gettlinge-Övre Segerstad. The eastern part of the Great Alvar (between the villages Övre Segerstad and Hulterstad) is characterised by large areas of flat bedrock, covered with weathered soils and almost no glacial deposits (see the physiognomic map of the Great Alvar of Öland in Königsson (1968). Königsson (1968) identified this part of the Great Alvar as one of the areas that has never been covered by closed forests since Öland rose above sea level in the postglacial Baltic Sea.

In the middle of the Great Alvar in this area, a north-south ridge of glacial deposits, less than one $\mathrm{km}$ wide and several $\mathrm{km}$ long, divides the Great Alvar in two halves-the eastern part described above and the western part with a more uneven topography. The ridge (Storåsen) is partly covered by closed vegetation that excludes habitats suitable for Heliantheтит. In its western and southern parts, the Storåsen ridge becomes more diffuse, dividing into narrow and shallow ridges of glacial deposits. This creates a mosaic of habitats in the west, some suitable for Helianthemum and others not, giving rise to a more fragmented population structure of Helianthemum than in the area east of Storåsen. A narrow arm (approximately $100 \mathrm{~m}$ wide, easily seen on aerial photographs, e.g. in Google Earth) of the Storåsen ridge continues several $\mathrm{km}$ in a southerly direction.

Five $\mathrm{W}-\mathrm{E}$ transects across the alvar were made in the southern part of the Stenåsen ridge, and H. oelandicum was recorded in one plot at each 50-m interval. The distance between transects was approximately $400 \mathrm{~m}$. The two northern transects (nos. 1 and 2) covered the entire width of the Great Alvar (approximately $6 \mathrm{~km}$ in this part of the Great Alvar), but the others were restricted to a few $\mathrm{km}$ on each side of the Storåsen arm.

\section{Sampling of plants for genetic analysis}

The analysis of the genetics behind hairs in the present study was mainly based on plants derived from two sites 
representing the extremes in the range of variation of pubescence. Site 36 was situated at the western margin of Vickleby alvar (Fig. 5), and site 27 was situated just east of the Storåsen arm (see above, Fig. 5). Most plants at site 27 were glabrous, while most plants at site 36 were hairy. The sampling at site 36 was extended beyond the site to represent patches of $H$. oelandicum var. oelandicum dominated by glabrous plant (A), hairy plants (C) and a mixture of glabrous and hairy plants (B), cf. Table 1. A few plants derived from three additional sites with hairiness between sites 27 and 36 were included in the genetic study in order to validate the results of crosses within and between sites 27 and 36 (one plant from site 26, two plants from site 113 and three plants from site 95, see Fig. 5).

Cuttings were transplanted from natural populations to the research garden at Lund University in the early 1990s. Plants surviving transplantation were multiplied during the following years to produce as many as ten replicates of each original plant (for further details see Widén 2017). These replicates were used in the experimental crosses (see below).

\section{Crosses for test of inheritance of pubescence}

The flowers of $H$. oelandicum do not produce nectar and are open in full sunshine, exposing numerous stamens. The filaments are sensitive to touch and bend outwards. The dry pollen is released successively in a few days in un-pollinated flowers (B. Widén personal observation). Several pollen-collecting visitors have been observed in the common garden, but wind pollination seems to prevail in the open and windy alvar habitats of Öland (Widén 2010; but see Janzon 1983).

Crosses were performed in a heated, insect-free chamber of a greenhouse, and offspring were raised in the common garden at Lund University. A pilot study in the 1970s used emasculated flowers and inflorescences isolated in paper bags, but the abortion rate was too high (B. Widén unpublished data). Since the species is self-incompatible (Herrera 1992; Widén 2017), the crosses in the present study were made without emasculation. Reciprocal crosses were obtained by gently rubbing together the two parental flowers.

Precautions were taken to prevent contamination with illegitimate pollen in the crosses. First, the plants were transferred from the outdoor common garden in late Mars or early April in order to flower indoors before the insect season. Secondly, all plants were replanted with fresh soil to remove any soil infected with insect eggs or pupae during the outdoor period. Thirdly, parental plants in a cross were spatially separated in the greenhouse from plants in other crosses by several metres to avoid contamination by air-borne pollen. The parental plants were used simultaneously in several crosses with the help of replicates (cuttings), individual crosses being separated from each other.
Offspring of each F1 family were kept together (5-6 individuals if possible) and separated from other F1 families with a few metres. F1 plants were usually crossed in pairwise combinations to produce $\mathrm{F} 2$ progeny. If the F1 plant was crossed in several combinations, inflorescences used in separate crosses were located on different parts of the plant to avoid contamination among F1 progeny. Inflorescences on individual plants not used for crosses were cut before flowering, but a few were left as control of autogamous selffertilisation/contamination (both on parental and F1 plants). The experimental design in the crossing programme did not exclude contamination, although contamination between parental crosses was unlikely, since the plants in different crosses were separated by several metres in the insect-free greenhouse. Crosses within F1 families, on the other hand, did not exclude contamination by mistake among F1 progeny, since the individual $\mathrm{F} 1$ progeny were kept together and the individual F1 plants were often crossed in more than one combination.

Cohorts of seeds of individual crosses had to be sown repeatedly over the years because of the high death rate of seedlings (for details of the treatments see Widén 2017). Helianthemum is known for its mycorrhizal association (Boursnell 1950), which has been suggested to be necessary for germination (Arrington and Kubitzki 2003; see also Proctor 1956) (seed germination and establishment of seedlings in general will be considered elsewhere). Some pilot crosses in the 1970s indicated that crosses between glabrous plants gave non-segregating F1s, while crosses between hairy plants gave various results. Analogous with results in Widén $(2015,2017)$ I formulate the 'a priori' hypothesis that the inheritance of glabrous plants is determined by a recessive allele of a Mendelian gene in $\mathrm{H}$. oelandicum var. oelandicum.

To test the 'a priori' hypothesis, the following types of crosses between morphs within and between populations were performed:

1. Crosses between glabrous plants assumed to be homozygous for the recessive allele ( $g l a b)$ determining the lack of bristles and stellate hairs; (a) within-population crosses (population 27 and 36), (b) crosses between plants derived from different populations (27, 36 and 113).

2. Crosses between bristled plants within populations (nos. 36 and 95); the plants can be either homozygous or heterozygous for the dominant allele (Brist), determining the presence of hairs.

3. Crosses between glabrous plants and hairy plants; (a) within populations (nos. 36 and 113), or (b) between populations (nos. 26, 27, 36, 113). The glabrous plants were assumed to be homozygous for the recessive allele determining the lack of bristles and stellate hairs. Hairy 
plants could be either homozygous or heterozygous for the dominant allele determining the presence of hairs.

Replicates of most plants used in the crossing programme $(n=25)$ were crossed in several combinations (mean $=2.3$, range 1-7), which allowed the genotype of parental plants to be determined (Table 1).

\section{Allele frequencies in local populations}

Variation in hairs was translated to allele frequencies in different samples. The allele frequencies $(q=\sqrt{ }$ (number of glabrous plants $/ n)$ ) were estimated assuming Hardy-Weinberg equilibrium (Helianthemum has a strong gametophytic self-incompatibility system, see above). Samples within and between populations were compared. The allele frequencies in field sample 1 for all populations were shown on a map, and allele frequencies along transects were shown in diagrams.

\section{Statistical tests}

Differences in hair scores among samples within populations were analysed using a nonparametric test, the Kruskal-Wallis test, while a Mann-Whitney $U$ test was used for differences between pairwise samples. The results of experimental crosses were evaluated by testing the goodness of fit of observed frequencies of the two hair morphs according to the 'a priori' hypothesis described above. The differences in allele frequencies along transects were tested by ANOVA (SPSS 22).

\section{Results}

\section{Hair scores}

Hair $_{(\mathrm{stab})}$ and hair (brl) scores in field sample 1 are shown in Fig. 6. Most plants (84\%) had no stellate hairs on the abaxial surface of the leaves, while a few plants (1.5\%) had a dense cover of stellate hairs (hair (stab) $_{\text {s }}$ scores 2.0-2.5). Most plants with hair $_{(\text {stab) }}$ scores $\geq 2$ were found in a restricted area (populations 35 and 235, see below), but scattered individuals
Table 1 Identity and characteristics of Helianthemum oelandicum var. oelandicum plants used in crosses

\begin{tabular}{|c|c|c|c|c|c|}
\hline Population & Plant identity & Hair score & $\begin{array}{l}\text { Number of crosses } \\
\text { involved in }\end{array}$ & Phenotype & Assumed genotype \\
\hline 26 & 9709 & 1 & 1 & Bristled & Brist/Brist \\
\hline 27 & 3928 & 0 & 2 & Glabrous & glab/glab \\
\hline 27 & 4987 & 0 & 1 & Glabrous & glab/glab \\
\hline 27 & 4988 & 0 & 1 & Glabrous & glab/glab \\
\hline 27 & 6333 & 0 & 2 & Glabrous & glab/glab \\
\hline 27 & 6380 & 0 & 7 & Glabrous & glab/glab \\
\hline 27 & 9470 & 0 & 2 & Glabrous & glab/glab \\
\hline 36 & 6353 & 1.5 & 2 & Bristled & Brist/glab \\
\hline 36 & 6355 & 1.5 & 4 & Bristled & Brist/glab \\
\hline 36 & 6398 & 1.5 & 6 & Bristled & 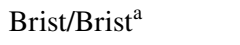 \\
\hline 36 & $\mathrm{~A} 2$ & 0 & 4 & Glabrous & glab/glab \\
\hline 36 & A3 & 0 & 1 & Glabrous & glab/glab \\
\hline 36 & A4 & 0 & 2 & Glabrous & glab/glab \\
\hline 36 & A5 & 0 & 4 & Glabrous & glab/glab \\
\hline 36 & B2 & 0 & 1 & Glabrous & glab/glab \\
\hline 36 & B4 & 0 & 3 & Glabrous & glab/glab \\
\hline 36 & B5 & 1 & 1 & Bristled & Brist/Brist \\
\hline 36 & $\mathrm{C} 2$ & 1.5 & 2 & Bristled & Brist/Brist \\
\hline 36 & $\mathrm{C} 4$ & 1.5 & 1 & Bristled & Brist/glab \\
\hline 36 & C5 & 1.5 & 2 & Bristled & Brist/glab \\
\hline 95 & 1 & 1 & 2 & Bristled & Brist/Brist \\
\hline 95 & 2 & 1 & 1 & Bristled & Brist/Brist \\
\hline 95 & 3 & 1 & 1 & & Brist/Brist \\
\hline 113 & 189 & 1 & 2 & Bristled & Brist/glab \\
\hline 113 & 193 & 0 & 2 & Glabrous & glab/glab \\
\hline
\end{tabular}

a See the text 


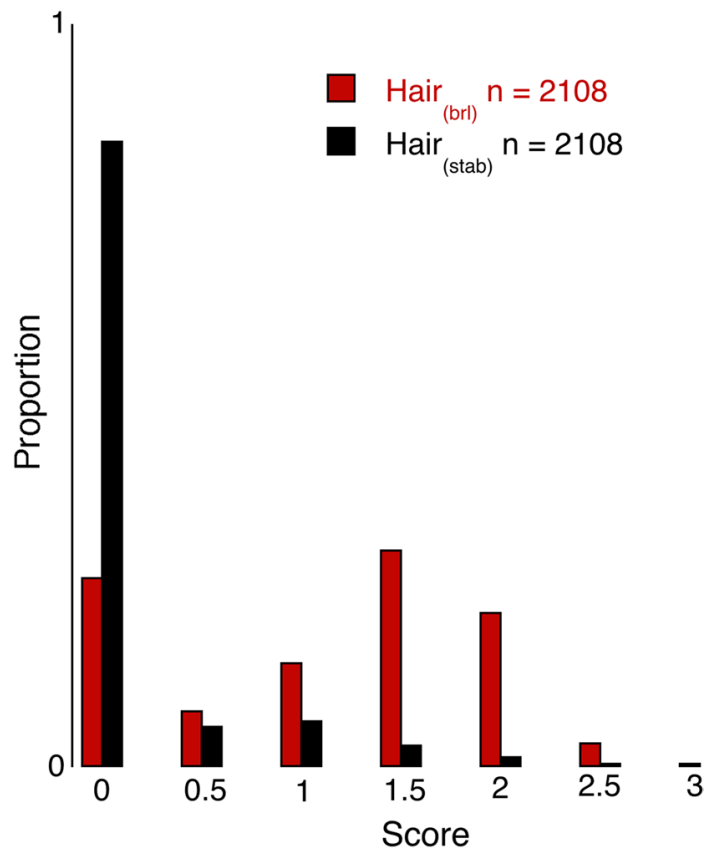

Fig. 6 The proportion of hair scores for bristles (red) and stellate hairs (black) in field sample 1 of Helianthemum oelandicum on Öland

were found elsewhere. Plants with hair ${ }_{(b r l)}$ score $=0$ did not have any stellate hairs, i.e. they were glabrous. Glabrous plants were found in $25 \%$ of field sample 1 . Among hairy plants, hair $_{(\text {brl })}$ score $=1.5$ was the most common and few plants (3.4\%) had hair (brl) $_{\text {sit }}$ score $\geq 2.5$ (Fig. 6).

The estimates of hair ${ }_{(b r l)}$ scores in the repeated samples of local populations used in the crossing programme are illustrated in Fig. 7. (Data on hair ${ }_{\text {(stab) }}$ scores are not shown, because few plants had stellate hairs on the abaxial surface of the leaf.) The distributions of hair (brl) and hair ${ }_{(\text {stab })}$ scores among the different samples within populations were compared, and no statistically significant differences were found for populations 26, 27 and 113 ( $p>0.38$, Kruskal-Wallis test). However, hair $_{(\text {brl })}$ and hair ${ }_{(\text {stab) }}$ scores differed among samples in population 36 ( $p<0.05$, Kruskal-Wallis test).

When I tested the repeatability of the classification of hairs in field sample $3(n=314)$, about one-third of the plants were classified as glabrous (hair ${ }_{(b r l)}$ score $=0$ and hair $_{\text {(stab) }}$ scores $=0$ ) when measured for the first time. When the same branch was classified again, only $1.9 \%$ of the plants classified as glabrous when measured for the first time $(n=107)$ had a hair (brl score $>0$, probably because a few inconspicuous bristles occurred on the peduncles. Consequently, glabrous plants can be identified accurately. If glabrous plants in the first classification were excluded, the differences between two measurements were $\leq 0.5$ scores in around $95 \%$ of the plants for hair ${ }_{(b r l)}$ scores and around
$90 \%$ for hair (stab) scores. The measurements of two different branches for the same plants were slightly less accurate (Table 2).

\section{Crosses}

\section{Self-incompatibility/contamination}

Inflorescences on parental plants left as controls did not set seed. Thus, there was no evidence of automatic self-fertilisation or contamination with illegitimate pollen in the parental crosses. The number of capsules on control inflorescences of F1 plants and the number of seeds (1-2) per capsule were so few that contamination with illegitimate pollen on F1 plants could be ignored.

\section{Hair scores in crosses}

Glabrous plants $(n=9)$ were crossed in nine combinations involving both within- and between-population crosses. All progeny in $\mathrm{F} 1(n=343)$ were glabrous, so there was no segregation in F1. All plants in F2 $(n=358)$ were glabrous except one, so hair ${ }_{(b r l)}$ and hair ${ }_{(\text {stab })}$ scores were zero (Online Resource 1). In the following, I assume that the genotype of glabrous plants is glab/glab.

All F1 plants $(n=191)$ except two were hairy in six crosses between hairy plants, and ten plants were glabrous in F2 ( $n=159)$ (Online Resource 1). Consequently, 3.4\% of the plants had hair (brl) $_{\text {br }}$ score $=0$, whereas $98 \%$ of the plants had hair $_{(\text {stab) }}$ score $=0$ (data not shown). All glabrous plants in these types of crosses arose in two crosses involving one parental plant (no 6398). I assume that the plants used in these types of crosses were homozygous for the dominant allele Brist. (The deviating crosses will be discussed below.)

Thirteen crosses between glabrous and hairy plants were performed (six within and seven between populations). The F1 plants were all hairy in three 'within-population' crosses and in two 'between-population' crosses; all other crosses segregated both glabrous and hairy plants. All crosses segregated in F2 (Online Resource 1). The distribution of hair scores showed that $99.9 \%$ of F1 and F2 plants had hair ${ }_{(\text {stab }}$ score $=0$ in 'within-population' crosses, whereas $68.6 \%$ of the progeny in 'between-population' crosses had hair ${ }_{(\text {stab }}$ score $=0$. Stellate hairs will be ignored in the following since they are so rare in $H$. oelandicum var. oelandicum, and hairy plants will be called bristled plants.

Bristled plants had significantly higher hair ${ }_{(b r l)}$ scores in 'between population' crosses than in 'within-population' crosses (Table 3). 

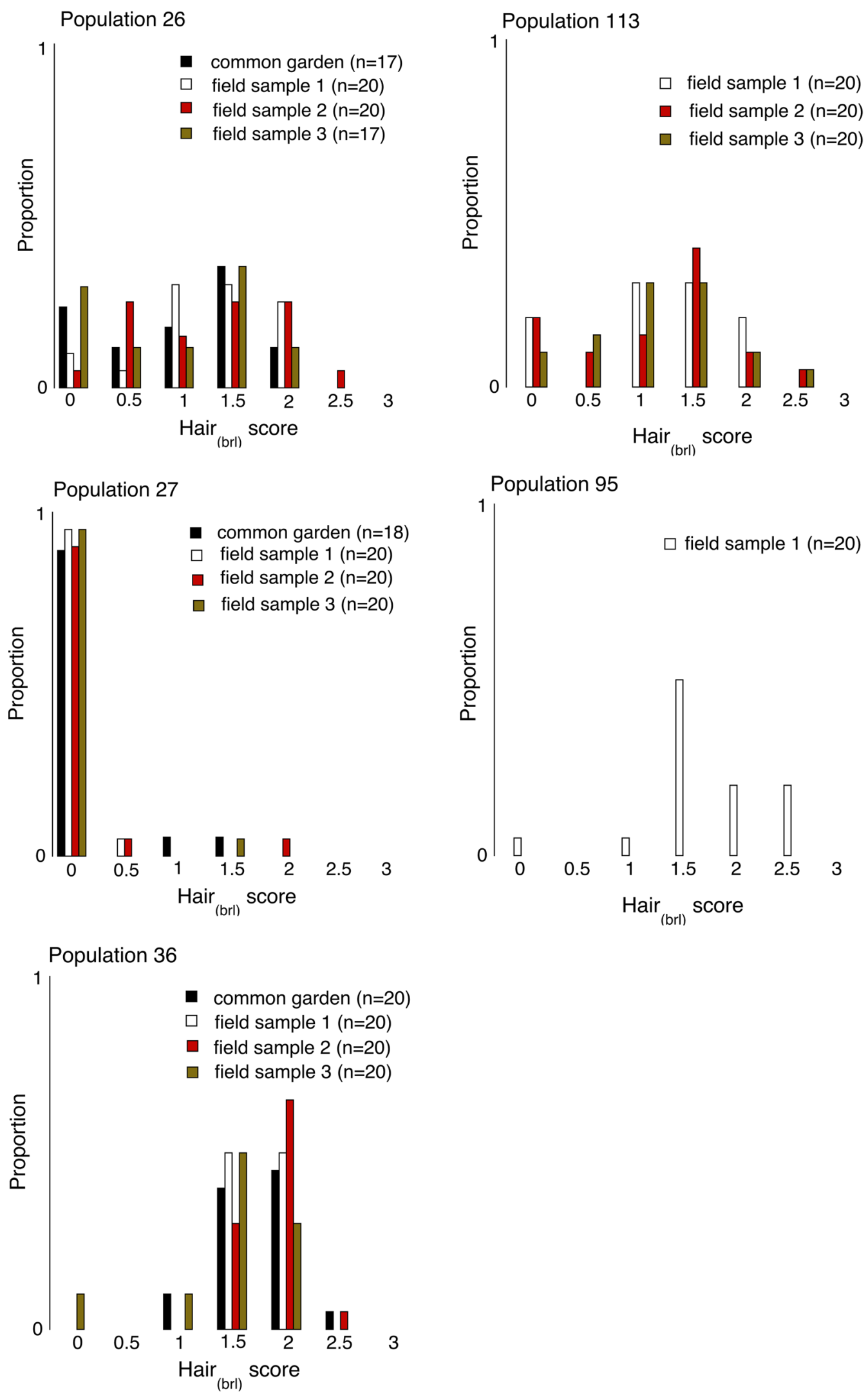

Fig. 7 The proportion of hair scores at sites $(100 \times 100 \mathrm{~m})$ used in crosses between plants in Helianthemum oelandicum var. oelandicum. Four randomly taken samples were compared at three sites (nos. 26, 27 and 36), three samples at site 113, and one sample at site 96 (see the text) 
Table 2 Accuracy in measuring density of hairs in Helianthemum oelandicum var. oelandicum, using repeated classifications of hair scores in field sample 3 (see the text)

\begin{tabular}{|c|c|c|c|c|}
\hline \multirow{2}{*}{$\begin{array}{l}\text { Score differences between } \\
\text { classifications }\end{array}$} & \multicolumn{2}{|l|}{ Hair $_{(\mathrm{brl})}$} & \multicolumn{2}{|l|}{ Hair $_{\text {(stab) }}$} \\
\hline & The same branch & $\begin{array}{l}\text { Two different } \\
\text { branches }\end{array}$ & The same branch & $\begin{array}{l}\text { Two } \\
\text { different } \\
\text { branches }\end{array}$ \\
\hline 0 & 0.665 & 0.567 & 0.828 & 0.783 \\
\hline 0.5 & 0.330 & 0.379 & 0.111 & 0.121 \\
\hline 1 & 0.005 & 0.044 & 0.061 & 0.086 \\
\hline 1.5 & 0.000 & 0.005 & 0.000 & 0.010 \\
\hline 2 & 0.000 & 0.005 & 0.000 & 0.000 \\
\hline$N$ & 203 & 203 & 198 & 198 \\
\hline
\end{tabular}

Frequency of score differences between two measurements in hairy plants. Hair ${ }_{(b r l)}=$ bristles on leaves, hair $_{\text {(stab) }}=$ stellate hairs on the abaxial surface of the leaves
Table 3 Mean hair (brl) score of bristled plants in crosses within and between populations of Helianthemum oelandicum var. oelandicum

\begin{tabular}{lllll}
\hline F & Type of cross & Mean hair score & SD & $N$ \\
\hline 1 & Within population & 1.06 & 0.373 & 404 \\
1 & Between population & 1.27 & 0.368 & 228 \\
2 & Within population & 1.07 & 0.350 & 402 \\
2 & Between population & 1.34 & 0.390 & 527 \\
\hline
\end{tabular}

The differences between 'within-population' crosses and 'betweenpopulation' crosses were significant for both F1 and F2 $(p<0.05$, Mann-Whiney $U$-test)

\section{Segregation of bristled and glabrous plants in crosses}

The five crosses between glabrous and bristled plants in Table 4 that did not segregate in F1 did segregate in F2. F2 progeny in three of these crosses segregated bristled and glabrous plants in the expected 3:1 ratio according to the 'a priori' hypothesis $\left(X^{2}<1.7, \mathrm{~ns}\right)$. The assumed genotypes of parental plants in these crosses were homozygous for the dominant allele Brist and for the recessive allele glab, respectively (Table 1). In two of the five crosses, segregation in $\mathrm{F} 2$ deviated from the expected 3:1 ratio $\left(X^{2}>5.5\right.$, $p<0.05)$. In both these crosses, the same parental plant was involved (no 6398 derived from population 36, cf. Table 4).

F1 progeny in eight crosses between glabrous and bristled plants segregated (Table 4), indicating that the bristled parental plants were heterozygous (Brist/glab). All crosses segregated $\mathrm{F} 1$ progeny in the expected $1: 1$ ratio according to the 'a priori' hypothesis (Table 4). Segregation in the seven F2 families that were produced cannot be tested directly on the data in Table 4, since data are based on heterogeneous crosses among F1 plants. However, testing is possible by splitting individual $\mathrm{F} 2$ families according to the type of cross among F1 plants (assuming the genotype of glabrous progeny to be glab/glab and the genotype of bristled progeny to be Brist/glab according to the 'a priori' hypothesis).
Segregation in most pairwise crosses accorded with the 'a priori' hypothesis (Table 5).

\section{Genotypes of parental plants}

The assumed genotypes of parental plants are shown in Table 1. Most plants $(64 \%)$ were used in more than one cross, and the estimation of the genotype is obvious and accurate in most cases. Only one plant, 6398 derived from population 36, was problematic. This bristled plant was assumed to be homozygous for the dominant allele Brist, and the plant was involved in six crosses, four of which deviated from the expected segregation ratio in F2 (Table 4). By analysing one of these deviating crosses with a substantial number of F2 progeny (cross 85), some light can be shed on the mechanisms behind the deviations. F1 progeny in this cross between plants A5 and 6398 (the cross assumed to be glab/glab $\times$ Brist/Brist) were all Brist/glab according to the 'a priori' hypothesis (Table 4). We can analyse the two mother lines separately in F2, since all crosses were reciprocal. F2 progeny derived from F1 plants with the mother A5 segregated according to the 'a priori' hypothesis ( 29 bristled plants and 10 glabrous plants, $X^{2}=0.009$, ns), whereas F2 progeny in the mother line 6398 did not segregate according to the 'a priori' hypothesis (58 bristled plants and 34 glabrous plants, $\left.X^{2}=7.015, p<0.01\right)$. In the other deviating cross involving plant 6398 assumed to be glab/glab $\times$ Brist/Brist (cross 109) most offspring in F1 belonged to the 6398 -mother line (33 of 34 plants). With only one glabrous offspring, segregation in F2 deviated significantly from the expected ratio $(p<0.01)$. However, if we pool the 6398 maternal lines in crosses 85 and 109, segregation in F2 did not deviate from the expected 3:1 (90 bristled plants: 35 glabrous plants, $X^{2}=0.60 \mathrm{~ns}$ ). 


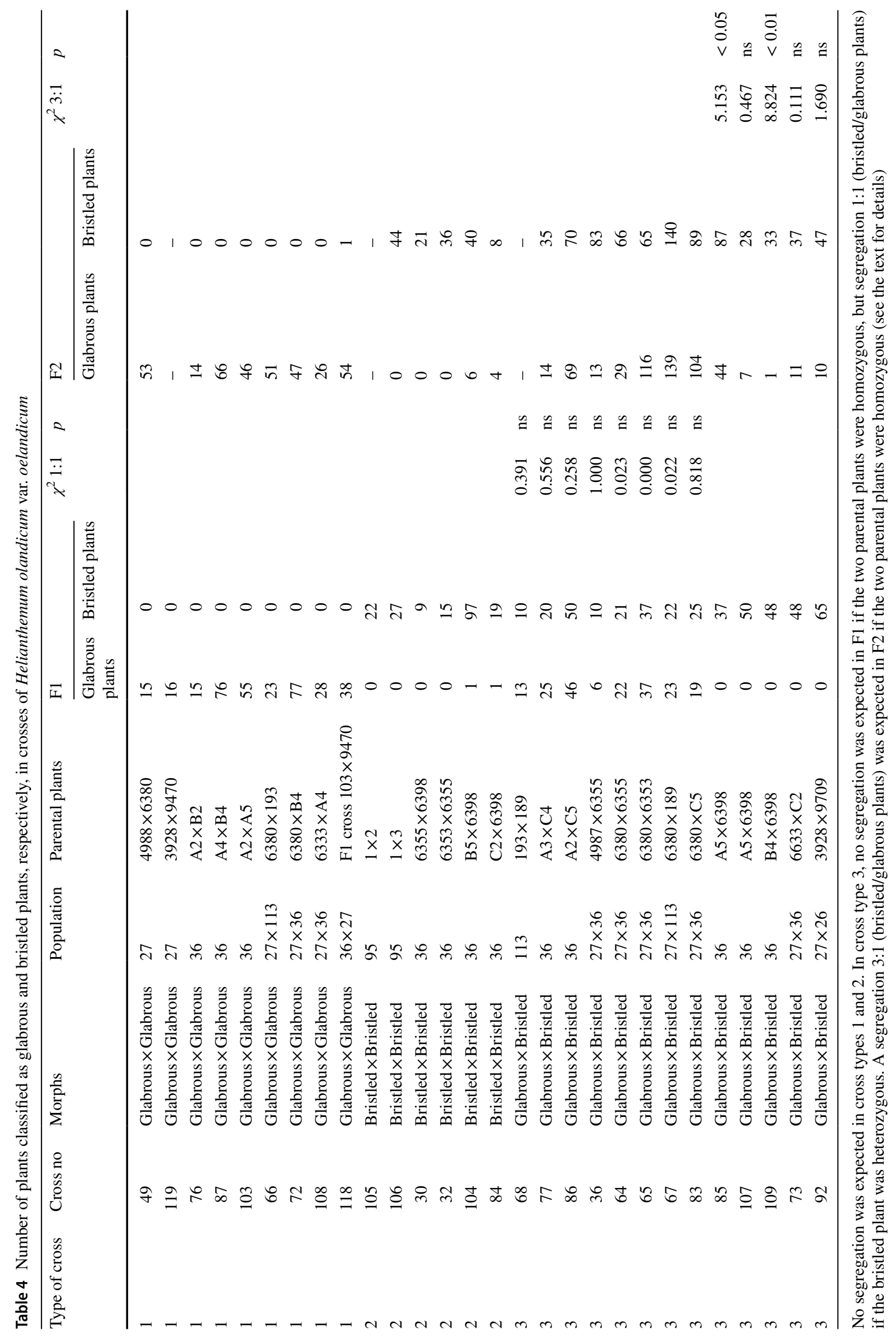


Table 5 Segregation in F2 progeny in crosses between glabrous and bristled F1 plants of Helianthemum oelandicum var. oelandicum with assumed genotypes glab/glab and Brist/ glab, respectively (cf. Table 4)

\begin{tabular}{|c|c|c|c|c|c|}
\hline \multirow{2}{*}{$\begin{array}{l}\text { Original } \\
\text { cross no }\end{array}$} & \multirow{2}{*}{$\begin{array}{l}\text { Phenotypes of } \mathrm{F} 1 \text { plants } \\
\text { in pairwise crosses }\end{array}$} & \multicolumn{2}{|c|}{ Segregation in F2 } & \multirow[t]{2}{*}{$X^{2}$} & \multirow[t]{2}{*}{$P$} \\
\hline & & Glabrous plants & Bristled plants & & \\
\hline 65 & Glabrous $\times$ Glabrous & 100 & 0 & - & - \\
\hline 67 & Glabrous $\times$ Glabrous & 89 & 1 & - & - \\
\hline 83 & Glabrous $\times$ Glabrous & 51 & 1 & - & - \\
\hline 86 & Glabrous $\times$ Glabrous & 50 & 0 & - & - \\
\hline 64 & Glabrous $\times$ Bristled & 19 & 30 & 2.469 & ns \\
\hline 67 & Glabrous $\times$ Bristled & 42 & 101 & 24.343 & $<0.001$ \\
\hline 77 & Glabrous $\times$ Bristled & 8 & 11 & 0.474 & ns \\
\hline 83 & Glabrous $\times$ Bristled & 52 & 88 & 9.257 & $<0.001$ \\
\hline 64 & Bristled $\times$ Bristled & 10 & 36 & 0.261 & $\mathrm{~ns}$ \\
\hline 65 & Bristled $\times$ Bristled & 27 & 62 & 1.352 & ns \\
\hline 67 & Bristled $\times$ Bristled & 9 & 38 & 0.858 & ns \\
\hline 77 & Bristled $\times$ Bristled & 6 & 24 & 0.400 & ns \\
\hline 86 & Bristled $\times$ Bristled & 27 & 76 & 0.081 & ns \\
\hline
\end{tabular}

One cross (no 36) had to be omitted because crosses among F1 plants were not strictly pairwise. The crossbristled plants $\times$ glabrous plants was assumed to segregate $1: 1$ and the cross-bristled plants $\times$ bristled plants 3:1 (bristled/glabrous)
Table 6 Correlation of allele frequency $(\mathrm{glab})$ between samples within populations (Online Resource 2)

\begin{tabular}{llll}
\hline Correlation between & $r$ & $p$ & $N$ \\
\hline Field sample 1 and common garden sample & 0.854 & 0.01 & 10 \\
Field sample 1 and field sample 2 & 0.977 & 0.01 & 16 \\
Field sample 1 and field sample 3 & 0.904 & 0.01 & 16 \\
Field sample 2 and field sample 3 & 0.898 & 0.01 & 16 \\
\hline
\end{tabular}

\section{Allele frequencies in local populations}

Using glabrous plants as an estimation of the recessive homozygotes ( $\mathrm{glab} / \mathrm{glab})$, I calculated the frequency of the recessive ( $\mathrm{glab}$ ) allele in the field samples and the common garden sample (Online Resource 2). The correlation of estimated frequencies of the glab allele among the three field samples within sites was significant (Table 6 and Fig. 8). There was also a highly significant correlation $(r=0.854$, $p<0.01)$ between the estimated frequencies in local populations based on field sample 1 and on offspring in the common garden sample (Table 6).

The distribution of the glab allele, based on field sample 1, was geographically structured (Fig. 5). A trend was that the frequency of the glab allele was homogeneous over large areas. The frequency of the recessive allele was especially high in an area of approximately $10 \mathrm{~km}^{2}$ on the eastern side of the middle part of the Great Alvar (from population 101 in the south to population 76 in the north, Fig. 5, the Stenåsen region, see below), and also, for example, in the two small alvar fragments at the northern margin of the distribution of $\mathrm{H}$. oelandicum on Öland (Fig. 5). A low frequency of

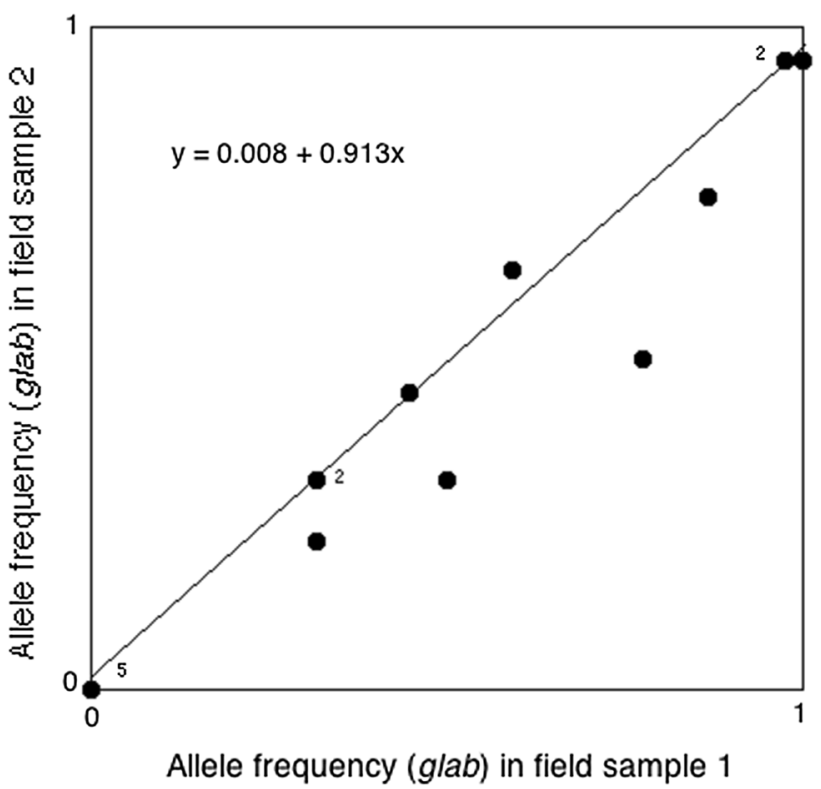

Fig. 8 Estimation of frequency of the recessive glab allele for glabrous plants in 16 local populations of Helianthemum oelandicum var. oelandicum, based on field samples 1 and $2 \mathrm{cf}$. Table 6)

the glab allele was found particularly on the western part of the Great Alvar, as well as in an isolated alvar fragment (south of the village Djupvik) at the northern margin of the distribution of $H$. oelandicum (Fig. 5). 


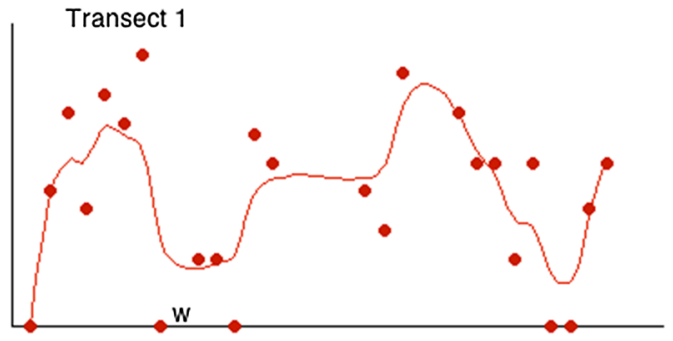

Transect 2
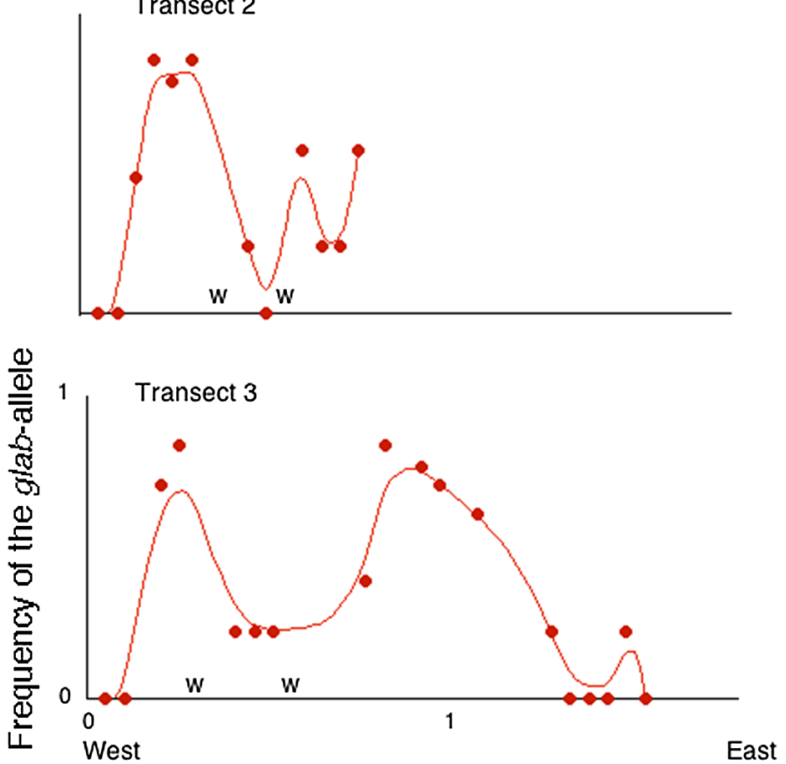

Distance from the western edge of the Great Alvar $(\mathrm{km})$

Fig. 9 The mean frequency of the recessive (glab) allele of Helianthemum oelandicum var. oelandicum at the western edge of the Great Alvar at Vickleby alvar (cf. Fig. 5). The means are based on two samples of five plants at each 50-m interval (see the text). The transects were numbered from north to south and were approximately $200 \mathrm{~m}$ apart. Transect 3 started at the local population 36 in Fig. 5. w $=$ Temporary flooded vegetation or wet meadows. The curves are produced by the option smooth in the Curve Fit of the KaleidaGraph program

\section{Population structure and allele frequencies in transects across the Great Alvar}

\section{Vickleby alvar}

The frequency of 50-m intervals with a density of at least five plants $/ \mathrm{m}^{2}$ along the three transects was 0.75 . When the frequency of the glab allele was calculated separately for the two plots at each 50-m distance, the two plots showed a significant correlation $(r=0.595, p<0.01, n=55)$. There was a positive correlation between the mean frequency of the glab allele at each 50-m interval and topography (Spearman's $r=0.559, p<0.01, n=55)$ meaning that glabrous plants were more common on flat bedrock than on ridges. The frequency of the glab allele changed along the transects, and the trend was the same for the three transects (Fig. 9). The frequency of the glab allele was zero at the edge of the alvar and increased successively to a maximum approaching 1.0 west of a temporary pool or moist grassland communities without Helianthemum. A dramatic decrease in the allele frequency occurred east of the wetlands for approximately $200 \mathrm{~m}$ along all three transects until the alvar vegetation changed again to moist grassland without Helianthemum. The frequency increased again further to the east, but the transects showed slightly different trends (Fig. 9).

\section{Stenåsen region}

Plants were found in less than half (0.44) of the 50-m intervals in the western half of the Great Alvar. Two-thirds of the 50-m intervals in the eastern part (0.68) had at least five plants $/ \mathrm{m}^{2}$ of $H$. oelandicum. The difference between the two halves of the Great Alvar was significant at $p<0.01$, with a trend of fewer differences in the southern transects (Table 7). The topography of the alvar plain was more even east of the Stenåsen ridge than in the west; on the scale
Table 7 Population structure and allele frequencies of Helianthemum oelandicum var. oelandicum in the Stenåsen region

\begin{tabular}{|c|c|c|c|c|c|c|c|c|}
\hline \multirow[t]{2}{*}{ Transect } & \multicolumn{4}{|c|}{ Western part of the Great Alvar } & \multicolumn{4}{|c|}{ Eastern part of the Great Alvar } \\
\hline & $\begin{array}{l}\text { Population } \\
\text { structure }\end{array}$ & $\begin{array}{l}\text { Frequency of } \\
\text { the glab allele }\end{array}$ & SD & $N$ & $\begin{array}{l}\text { Population } \\
\text { structure }\end{array}$ & $\begin{array}{l}\text { Frequency of } \\
\text { the glab allele }\end{array}$ & SD & $N$ \\
\hline 1 & 0.30 & 0.27 & 0.193 & 18 & 0.68 & 0.91 & 0.088 & 41 \\
\hline 2 & 0.38 & 0.34 & 0.198 & 18 & 0.80 & 0.90 & 0.145 & 36 \\
\hline 3 & 0.48 & 0.37 & 0.132 & 13 & 0.70 & 0.86 & 0.109 & 23 \\
\hline 4 & 0.50 & 0.44 & 0.293 & 15 & 0.57 & 0.87 & 0.146 & 17 \\
\hline 5 & 0.56 & 0.53 & 0.110 & 5 & 0.71 & 0.75 & 0.123 & 12 \\
\hline
\end{tabular}

The western and eastern parts of the Great Alvar are separated by a narrow, north-south-directed glaciofluvial ridge (see the text and Fig. 10). Population structure is the proportion of 50-m distances along the transects that has a density of $\geq 5$ flowering plants 
Fig. 10 Transect from west to east across the Great Alvar at the Stenåsen region (see Fig. 5). The transects were numbered from north to south and were approximately $400 \mathrm{~m}$ apart. Transect 2 was situated approximately $100 \mathrm{~m}$ north of permanent plots at site 27 . The frequency of the recessive allele ( $\mathrm{glab}$ ) of Helianthemum oelandicum var. oelandicum (if present) at each 50-m interval was calculated as an average of three neighbouring samples (to compensate for the low number of plants per plot). The eastern edge of the Stenåsen ridge is marked with open circles on the $x$-axes. The curves are produced by the option smooth in the Curve Fit of the KaleidaGraph program

from 1 (low glaciofluvial ridges) to 4 (even alvar plain), the averages were 3.6 and 3.0 for east and west, respectively $(p<0.001$, Mann-Whitney $U$ test). The number of plants per $\mathrm{m}^{2}$ did not differ between west and east. The correlation between the mean frequency of the glab allele at each 50-m interval and topography is significant (Spearman's $r=0.413$, $p<0.01, n=197)$. The average frequency of the glab allele in the western half of the Great Alvar increased from 0.27 in the northern transect to 0.53 in the most southern transect (Table 7). The corresponding changes in the eastern part of the alvar were from 0.91 to 0.75 . The differences in average allele frequencies between the two halves of the Great Alvar are significant at $p<0.001$. From Fig. 10, it can be seen that the homogeneous eastern populations had a central core of high frequency of the recessive allele and that the frequency decreased towards the Stenåsen ridge and towards the eastern margin of the Great Alvar.

\section{Discussion}

\section{Phenotypes}

The phenotype of glabrous plants was easy to identify, since the plant lacks bristles and stellate hairs on all parts, although $<2 \%$ of the glabrous plants may have few inconspicuous bristles that risk being overlooked. The phenotypes of bristled plants vary greatly, and there was substantial overlap in density of hairs between bristled plants of var. oelandicum and bristled plants of var. canescens (Widén 2017). Stellate hairs on the abaxial surface of the leaves were rare and often inconspicuous in var. oelandicum, and the density of stellate hairs very seldom overlap with the density in stellated plants of var. canescens, which had hair ${ }_{\text {(stab) }}$ score $=2-3$. Given the probability of finding the correct hair score in the interval of \pm 0.5 scores used in the present study, the few bristled plants of var. oelandicum with hair ${ }_{\text {(stab) }}$ score $=2-2.5$ were hardly identical to stellated plants of var. canescens.

\section{Accuracy of methods}

Crossing experiments in the present study were designed to avoid contamination with illegitimate pollen in
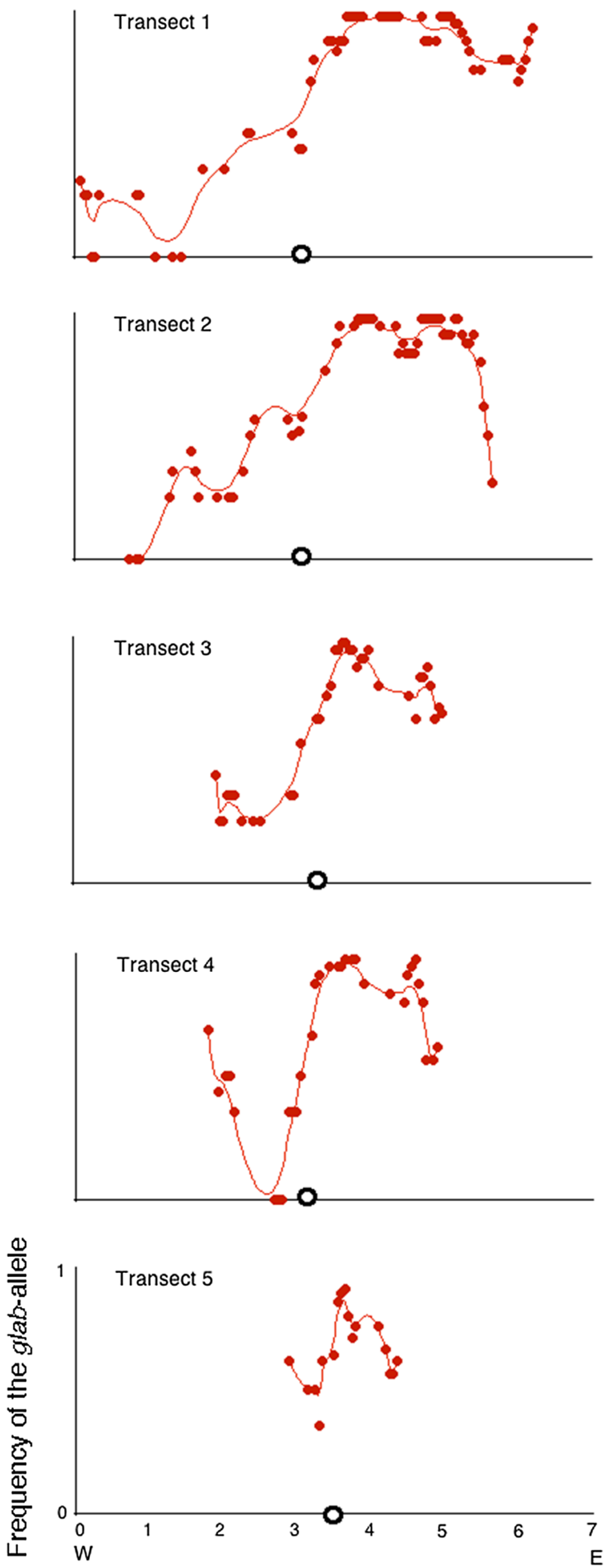

Distance from the western edge of the Great Alvar $(\mathrm{km})$

self-incompatible, non-emasculated flowers. Although insect visitors are frequent outdoors in the common garden, wind pollination prevails in $H$. oelandicum on Öland, where insects are rare in windy habitats (B. Widén unpublished data). Individual pollen grains can be observed (with a hand 
lens) leaving the anthers in weak air currents in the greenhouse (B. Widén personal observation). I did not detect any contamination with illegitimate pollen on control inflorescences or isolated parental plants. If all $\mathrm{F} 1$ plants in crosses not expected to segregate in $\mathrm{F} 1$ are summed $(n=782)$, only 2 offspring deviated from expectation $(0.3 \%)$ and both involved crosses with plant 6398 (see below). Thus, separating pairs of parental plants by a few meters appears to have prevented cross-contamination.

Air-born pollen transferred among siblings within F1 families was not fully prevented with the present crossing design. The few investigated capsules on control inflorescences gave a maximum of 5 seeds per plant, which represented only a small fraction of seeds produced in a legitimate cross. (A full account of flower biology and seed set will be presented elsewhere.) In most cases (crosses within homogenous F1 families), contamination among siblings had no meaning for the segregation ratios. Contamination among siblings can only distort segregation in pairwise crosses in heterogeneous F1 families.

Progeny in crosses between glabrous and bristled plants did segregate according to the 'a priori' hypothesis of a Mendelian gene with one dominant and one recessive allele, except in a few crosses. Some of the deviations from expected segregation could be caused by the methods used, because occasional contamination by illegitimate pollen cannot be excluded (see above). However, one plant derived from population 36 (plant 6398) was involved in most of the crosses that deviated from expected segregation ratio, suggesting that the deviations were unique to this plant. The mechanism behind this deviation is obscure. First, the number of offspring deviating from expected segregation is too large to be explained by accidental contamination by illegitimate pollen. Secondly, several but not all crosses involving this plant deviated from expected segregation ratios. Thirdly, when ignoring the paternal plants in the crosses between glabrous and bristled plants assumed to be glab/glab and Brist/ Brist, respectively, and pooling offspring of the maternal line (6398) in the two deviating crosses, segregation in F2 did not deviate from the expected ratio.

Simple traits such as hair formation can be influenced by several genes (Scriver and Waters 1999). For instance, glabrousness is caused by mutations in at least two genes in Arabidopsis thaliana (Herman and Marks 1989; Sawa 2002). So far, there is no evidence that several genes per se cause variation in glabrousness among offspring of the mother plant 6398. A more plausible explanation for the deviating segregation in crosses involving this plant has to do with seed germination and establishment. The mycorrhizal association between fungi and the radicle is an intricate mechanism (Boursnell 1950), and the death rate among seedlings is high and environmentally influenced (Widén 1987, B. Widén unpublished data). The young seedlings are difficult to classify with respect to hairs, and because of logistics scoring has to wait several months after germination. Thus, cohorts of seedlings have already been selected when they are phenotyped. The reason why offspring of plant 6398 survive differently than offspring of other plants is obscure, but survival of seedlings could be influenced by interactions between cytoplasmic factors of plant 6398 and the genotypes of offspring. (A thorough account of seed germination and establishment of seedlings will be given elsewhere.)

\section{Inheritance}

The inheritance of the virtually continuous variation in bristles on leaves in H. oelandicum var. oelandicum showed the same type of inheritance as variation of stellate hairs on the abaxial surface of leaves in $H$. nummularium and $H$. oelandicum var. canescens (Widén 2015, 2017). The density of hairs varied between local populations in all taxa. The F2 segregation in crosses within and between populations differed slightly, in a way suggesting that quantitative genes are involved in the regulation of hair density. Significant heritability of hair density has been found in several species (cf. Kärkkäinen and Ågren 2002).

In crosses between plants assumed to be homozygous for phenotypes above and below a certain threshold of hair density, segregation in F2s did not deviate from a 3:1 ratio, suggesting that a Mendelian gene with one dominant allele and one recessive allele regulates the threshold density. The threshold density in $H$. oelandicum var. oelandicum was hairy plants versus non-hairy plants, and the threshold in the other two taxa of Helianthemum was plants with hair $_{(\text {stab) }}$ score $<2$ and plants with hair (stab) $_{\text {s }}$ score $\geq 2$ (Widén 2015, 2017). The dominant allele in all three taxa gave rise to phenotypes with variable density of hairs, and the homoand heterozygotes of the dominant allele cannot be distinguished. Homo- and heterozygotes in H. oelandicum var. canescens and $H$. nummularium have bristles and hair ${ }_{(\text {stab) }}$ score $<2$. Homo- and heterozygotes of the dominant allele in H. oelandicum var. oelandicum have bristles and sometimes a low density of stellate hairs, although they are rare and inconspicuous. The recessive alleles gave rise to different phenotypes in the three taxa; glabrous plants in $H$. oelandicum var. oelandicum and hairy plants with a whitish abaxial surface of the leaves (hair (stab) $_{\text {s }}$ score $\geq 2$ ) in $H$. oelandicum var. canescens and $H$. nummularium. The two taxa with stellated morphs (and the same mechanisms of inheritance) belong to two different, well-defined subgenera of Helianthemum (Aparicio et al. 2017), whereas var. canescens and var. oelandicum with different recessive morphs belong to the same subspecies of $H$. oelandicum. 


\section{Candidate genes and natural selection}

Production and development of hairs are often regulated by many genes (Larkin et al. 1996; Schwab et al. 2000; Schellmann and Hülskamp 2005; Ishida et al. 2008), although several studies have shown that the inheritance of glabrous plants or hairless parts of plants has a simple Mendelian background involving recessive alleles (e.g. Westerberg 1992; Kärkkäinen and Ågren 2002; Yol and Uzun 2011). The molecular background of hair formation is well studied in the model organism A. thaliana (L.) Heynh. and a few other species, e.g. Mimulus guttatus DC and cotton (Hamphries et al. 2005; Ishida et al. 2008; Scoville et al. 2011). A number of genes involved in trichome production have been identified in A. thaliana (Ishida et al. 2008), some of which have been shown to have functional homologues in other unrelated species, e.g. GLABRA2 in A. thaliana and GaHOXI in cotton (Guan et al. 2008). Kivimäki et al. (2007) suggested that independent mutations in the regulatory gene GLABRAl gave rise to parallel evolution of glabrous plants in natural populations of Arabidopsis lyrata (L.) O’Kane and Al-Shehbaz in northern Europe.

Polymorphism in hairs has often been explained by the significant advantage of hairs as defence/protection against biotic and/or abiotic stresses (e.g. Levin 1973; Johnson 1975; Ågren and Schemske 1993; Espigares and Peco 1995; Kivimäki et al. 2007). Selective grazing on hairless plants by insects or molluscs has been pointed out as explanation for polymorphism of hairlessness in natural populations (e.g. Westerberg and Nyberg 1995; Kivimäki et al. 2007; Løe et al. 2007; but see Kawagoe et al. 2011). Herbivory plays a minor role in $H$. oelandicum, but the recurrent severe drought has great impact on reproduction and survival of this species (Sterner 1936a; B. Widén unpublished data). The polymorphism in pubescence of $H$. oelandicum is best understood in the light of the mosaic of drainage conditions of the alvar vegetation on Öland (Sterner 1936a; Rosén 1982; Bengtsson et al. 1988; Widén1988). Tyler et al. (2018) have recently shown that periodical inundation is one of the most important environmental factors determining the diversity of bryophytes on the Great Alvar.

Glabrous and bristled plants may be ecotypes in the sense of Turesson (1922), although they only differ by two alleles at one locus. We do not know if natural selection acts directly on these alleles or on linked genes. Phenotypic selection can act on any life cycle stage, e.g. the slow growing seedlings are sensitive to summer drought and frost heaving during winter (Widén 1987, B. Widén unpublished data). Glabrous seedlings may be well adapted to periods of submerging in autumn and winter by analogy with water plants that often are glabrous. Bristled seedlings, on the other hand, may have an advantage during summer if hairs imply protection against drought. Studies in permanent plots (Widén 1980) have shown that survival of adults and seed production vary between years and sites (B. Widén unpublished data). How these life cycle stages are affected by drought and periodical inundation, and how these environmental factors are related to allele frequencies for pubescence in $\mathrm{H}$. oelandicum will be discussed elsewhere (B. Widén unpublished data). However, further studies are needed to fully understand the mechanism behind the phenotypic selection on the two morphs of $H$. oelandicum var. oelandicum.

\section{Geographical pattern in allele frequencies}

The diversity of hairs in H. oelandicum on Öland has long been observed by local botanists. Ahlquist (1821) recognised glabrous plants as forma denudatum, and several authors have referred to pubescence in $H$. oelandicum on Öland (e.g. Hartman 1820; Fries 1823; Törnblom 1908; Du Rietz 1923; Sterner 1936b). Widén (1988), using a hair index, confirmed the geographical structure in hair diversity suggested by Sterner (1936b), who recognised, partly based on pubescence, as many as three species on Öland (cf. Widén 2017). Two of his species, H. canum and $H$. italicum subsp. rupifragum, identical to $H$. oelandicum var. canescens and restricted to the southernmost part of Öland (Fig. 1), were also reported from scattered localities further to the north on the Great Alvar (Sterner 1936b). His records of $H$. canum outside the core area of $H$. oelandicum var. canescens correspond to the scattered bristled plants with hair (stab) score $\geq 2$ found in the present study. All plants in the present study had the CF phenology, so by definition cannot belong to $H$. oelandicum var. canescens.

The sampling design used revealed that the frequency of the recessive glab allele was often homogeneous over distances of $100 \mathrm{~m}$, since the correlation of allele frequencies in repeated samples within sites was highly significant. Furthermore, allele frequencies in adjacent sites were usually very similar, but frequencies along transects revealed both gradual and abrupt changes over distances of 50-100 m. The most homogeneous sites with a high frequency of the recessive allele were often found in the eastern part of the Great Alvar, where the glab allele could dominate over tens of $\mathrm{km}^{2}$. In the western part of the Great Alvar, the frequency of the glab allele was often low. The same trend of spatially restricted high homozygosity was found of the recessive can allele in $H$. oelandicum var. canescens (Widén 2017), but the areas of high homozygosity of the recessive allele in this morph were much smaller than in $H$. oelandicum var. oelandicum. 


\section{Habitat heterogeneity}

The edaphic and drainage conditions of the dry alvar grasslands of Öland create fine-scale habitat variation with a number of plant communities (Albertsson 1950; Rosén 1982; Bengtsson et al. 1988; Tyler et al. 2018). The heterogeneity in depths of neutral to base-rich soils creates environmental gradients over distances from tens of metres to tens of centimetres (Sterner 1936a; Prentice et al. 1995, 2015). Helianthemum oelandicum var. oelandicum with a broad ecological amplitude is found in many of these plant communities (Bengtsson et al. 1988), and the species often occurs in large, virtually continuous populations (Sterner 1936a; Widén 1988).

The frequency of the recessive allele was low in welldrained habitats such as shallow ridges of glacial deposits, especially at the western margin of the Great Alvar. Low precipitation and a high number of sunshine hours in spring (Widén 1980; Rosén 1982) mean that these ridges dry out earlier than neighbouring poorly drained habitats on weathered soils. These warm, well-drained ridges at the western margin of the Great Alvar favour early flowering of $\mathrm{H}$. oelandicum (1-2 weeks earlier) compared to flowering in cooler weathered soils (Sterner 1936a; B. Widén unpublished data).

These local conditions create gradients of change in population structure and allele frequencies at a finer spatial scale. For example, site 36 at Vickleby alvar is situated $50 \mathrm{~m}$ east of the alvar edge in well-drained habitats (Fig. 5). This local population showed a low frequency of the glab allele both in the field samples and in the transects. The frequency increased after only $150 \mathrm{~m}$ to the east as the habitat became less well drained (Fig. 9). The frequency of the recessive allele then drops dramatically about 400 m east of the alvar edge, just east of a temporary pool dammed by an area of drier habitats. Local populations characterised by homogeneous allele frequencies at Vickleby alvar seem to have a north-south orientation (at least $400 \mathrm{~m}$ covered by the three transects) and an E-W width of 150-300 m created by the local mosaic of drainage conditions.

Summer precipitation fluctuates between years (Widén 1980; Rosén 1982), and drought can be an important environmental factor causing widespread death of plants with shallow roots on thin soils in the alvar grasslands (Prentice et al. 1995). Natural selection can change gene frequencies correlated with gradients of soil depths over distances of tens of centimetres after severe drought (Prentice et al. 2015). Species like $H$. oelandicum with an extensive root system, which reaches down to moisture in fissures in the calcareous bedrock, are less sensitive and can survive even severe drought (Sterner 1936a; Widén 1980; Bengtsson 1993). Early drought in spring may affect seed set, but $H$. oelandicum var. oelandicum has usually finished seed production when the summer drought occurs in July (B. Widén unpublished data). However, devastating drought that occurs at irregular intervals, usually at about ten-year intervals (Prentice et al. 1995), has a significant impact on plant survival in many communities of the alvar grasslands on Öland, including H. oelandicum (B. Widén unpublished data).

\section{Future perspectives}

No other detailed mapping of diversity of pubescence in natural populations of Helianthemum has been published, but the classical taxonomical literature indicates that the patterns described in the present study and in Widén $(2015,2017)$ are not unique for $H$. oelandicum or $H$. nummularium. One source of information is the work of Janchen $(1907,1909)$. $\mathrm{He}$ addressed variation in pubescence in both the $H$. nummularium and the $H$. oelandicum complexes and described many taxa that are now only of historical interest. Common to many of his higher taxa (species) was parallel evolution of morphs with different densities of hairs. These morphs were sometimes allopatric, but often sympatric. For example, he described morphs with and without a dense cover of stellate hairs on the adaxial surface of the leaf, traits not currently used as key characters, e.g. in his H. tomentosum (Scop.) Spreng. and H. canum (L.) Baumg. The frequency of plants with or without these traits varies within and between natural populations in H. oelandicum subsp. incanum (B. Widén personal observation).

Future analyses of crosses between morphs will reveal if the genetic background of these and other hair characters in Helianthemum is the same as that found in the present study and in the studies of $H$. nummularium and $H$. oelandicum var. canescens (Widén 2015, 2017). Further studies will also clarify if one or several Mendelian genes are involved in the regulation of hair phenotypes, and the use of next-generation sequencing techniques will reveal the molecular background of variation in pubescence in Helianthemum.

Acknowledgements I thank Lund University for greenhouse and common garden facilities from the early 1970s to the present day, the former ecological station of Uppsala University at Ölands Skogsby, and the Station Linné research station for providing a base during the fieldwork on Öland. I acknowledge the Microscopy Facility at the Department of Biology, Lund University, for the SEM photographs. I thank Marie Widén (MW) for assistance in the field and the common garden, Werner Smidt and MW for technical help with figures, Thomas Gunnarsson, Eje Rosén and MW for photographs, and CommunicAID for language review and revision. I also appreciate valuable suggestions made by two anonymous reviewers.

\section{Compliance with ethical standards}

Conflict of interest The author declares that he has no conflict of interest.

Open Access This article is distributed under the terms of the Creative Commons Attribution 4.0 International License (http://creativeco 
mmons.org/licenses/by/4.0/), which permits unrestricted use, distribution, and reproduction in any medium, provided you give appropriate credit to the original author(s) and the source, provide a link to the Creative Commons license, and indicate if changes were made.

\section{Information on Electronic Supplementary Materi- als}

Online resource 1. Number of plants with different hair ${ }_{(b r l)}$ scores in crosses between plants of Helianthemum oelandicum var. oelandicum. Online resource 2. Coordinates of sites with Helianthemum oelandicum var. oelandicum on Öland and frequencies of the glab allele in field samples 1-3 and the common garden sample.

\section{References}

Ågren J, Schemske D (1993) The cost of defence against herbivores: an experimental study of trichome production in Brassica rapa. Amer Naturalist 141:338-350

Ahlquist A (1821) Anmärkningar om Ölands fysiska beskaffenhet och vegetation. Kungl Svenska Vetensk Akad Handl 1821:278-304

Albertsson N (1950) Das grosse südliche Alvar der Insel Öland. Eine pflanzensociologische Übersicht.Svensk Bot Tidskr 44:269-331

Aparicio A, Martín-Hernanz S, Parejo-Farnés C, Arroyo J, Lavergne S, Yesilyurt EB, Zang M-L, Rubio E, Albaladejo RG (2017) Phylogenetic reconstruction of the genus Helianthemum (Cistaceae) using plastid and nuclear DNA-sequences: systematics and evolutionary inferences. Taxon 66:868-885. https://doi.org/10.12705 1664.5

Arrington JM, Kubitzki K (2003) Cistaceae. In Kubitzki K, Berger C (eds) The families and genera of vascular plants V. Malvales, Capparales and non-betallain Caryophyllales. Springer, Berlin, pp 62-70

Bengtsson K (1993) Fumana procumbens on Öland-population dynamics of a disjunct species at the northern limit of its range. J Ecol 81:745-758

Bengtsson K, Prentice HC, Rosén E, Moberg R, Sjögren E (1988) The dry alvar grasslands of Öland: ecological amplitudes of plant species in relation to vegetation composition. Acta Phytogeogr Suec 76:21-46

Berglund BE (1966) Late-quaternary vegetation in eastern Blekinge, south-eastern Sweden. A pollen-analytical study. 1. Late-glacial time. Opera botanica. Soc Bot Lundensi Suppl Ser 12:1-79

Björck S (1995) A review of the history of the Baltic Sea, 13.0-8.0 ka BP. Quatern Int 27:19-40

Boursnell JG (1950) The symbiotic seed-born fungus in the Cistaceae I. Distribution and function of the fungus in the seeding and in the tissues of the mature plant. Ann Bot (Oxford) 14:217-243

Du Rietz GE (1923) De svenska Helianthemum-arterna. Bot Not 76:435-446

Ekstam U, Forshed M (2002) Svenska alvarmarker: historia och ekologi. Naturvårdsverkets Förlag, Stockholm

Espigares T, Peco B (1995) Mediterranean annual pasture dynamics: impact of autumn drought. J Ecol 83:135-142

Fiz-Palacios O, Valcárcel V (2013) From Messinian crisis to Mediterranean climate: a temporal gap of diversification recovered from multiple plant phylogenies. Perspect Pl Ecol Evol Syst $15: 130-137$

Fries E (1823) Novitiae florae suecicae. Berlings, Lund

Grosser W (1903) Cistaceae. Pflanzenreich 4:193

Guan XY, Li QJ, Shan CM, Wang S, Mao YB, Wang LJ, Chen XY (2008) The HD-Zip IV Gene GaHOXI from cotton is functional homologue of the Arabidopsis GLABRA2. Physiol Pl 134:174182. https://doi.org/10.1111/j.1399-3054.2008.01115.x

Guzmán B, Vargas P (2009) Historical biogeography and character evolution of Cistaceae (Malvales) based on analysis of plastid $r b c L$ and $t r n L-t r n F$ sequences. Org Divers Evol 9:83-99. https:// doi.org/10.1016/j.ode.2009.01.001

Hamphries JA, Walker AR, Timmis JN, Orford SJ (2005) Two WDrepeat genes from cotton are functional homologues of the Arabidopsis thaliana TRANSPARENT TESTA GLABRA1 (TT) gene. Pl Molec Biol 57:67-81. https://doi.org/10.1007/s11103-004-6768-1

Hartman C (1820) Handbok i skandinaviens flora. Haeggström, Stockholm

Herman PL, Marks MD (1989) Trichome development in Arabidopsis thaliana. II Isolation and complementation of the GLABROUS1 gene. Pl Cell 1:1051-1055

Herrera J (1992) Flower variation and breeding system in the Cistaceae. Pl Syst Evol 179:245-255

Hewitt G (2000) The genetic legacy of the Quaternary ice ages. Nature 405:907-913

Ishida T, Kurata T, Okada K, Wada T (2008) A genetic regulatory network in the development of trichomes and root hairs. Annual Rev Pl Biol 59:365-386

Iversen J (1973) The development of Denmark's nature since the last glacial. Danmarks Geol Unders $\emptyset 1$ 7-C:1-126

Janchen E (1907) Helianthemum canum (L.) Baumg. und seine nächsten verwandten. Abh Zool-Bot Ges Österreich 4:1-67

Janchen E (1909) Die Cistaceen Österreich-Ungarns. Mitt Naturwiss Vereines Univ Wien 7:1-124

Janzon L-A (1983) Aculeate hymenoptera and other flower visiting insects on the Great Alvar of Öland Sweden. Entomol Tidsk 104:169-182

Johnson HB (1975) Plant pubescence: an ecological perspective. Bot Rev 41:232-258

Kärkkäinen K, Ågren J (2002) Genetic basis of trichome production in Arabidopsis lyrata. Hereditas 136:219-226

Kawagoe T, Shimizu KK, Kakutani T, Kudoh H (2011) Coexistence of trichome variation in a natural plant population: a combined study using ecological and candidate gene approaches. PLoS ONE 6:e22184. https://doi.org/10.1371/journal.pone.0022184

Kivimäki M, Kärkkäinen K, Gaudeul M, Løe G (2007) Gene, phenotype and function: GLABROUS1 and resistance to herbivory in natural populations of Arabidopsis lyrata. Molec Ecol 16:453462. https://doi.org/10.1111/j.1365-294X.2007.03109.x

Königsson L-K (1968) The holocene history of the Great Alvar of Öland. Acta Phytogeogr Suec 55:1-172

Krahulec F, Rosén E, van der Maarel E (1986) Preliminary classification and ecology of dry grassland communities on Ölands Stora Alvar (Sweden). Nordic J Bot 6:797-809

Larkin JC, Young N, Prigge M, Marks MD (1996) The control of trichome spacing and number in Arabidopsis. Development 122:997-1005

Levin DA (1973) The role of trichomes in plant defence. Quatern Rev Biol 48:3-15

Løe G, Toräng P, Gaudeul M, Ågren J (2007) Trichome production and spatiotemporal variation in herbivory in the perennial herb Arabidopsis lyrata. Oikos 116:134-142. https://doi.org/10.111 1/j.2006.0030-1299.15022.x

Mortensen MF, Birks HH, Christensen C, Holm J, Noe-Nygaard N, Odgaard BV, Olsen J, Rasmussen KL (2011) Lateglacial vegetation development in Denmark: new evidence based on macrofossils and pollen from Slotseng, a small-scale site in southern Jutland. Quatern Sci Rev 30:2534-2550. https://doi.org/10.1016/j. quascirev.2011.04.018

Prentice HC, Lönn M, Lefkovitch LP, Runyeon H (1995) Association between allele frequencies in Festuca ovina and habitat variation 
in the allvar grasslands on the Baltic island of Öland. J Ecol 83:391-402

Prentice HC, Li Y, Lönn M, Tunlid A, Ghatnekar L (2015) A horizontal transferred nuclear gene is associated with microhabitat variation in a natural plant population. Proc Roy Soc B 282:20152453. https ://doi.org/10.1098/rspb.2015.2453

Proctor MCF (1956) Biological flora of the British Isles. Helianthmum Mill. J Ecol 44:675-692

Proctor MCF, Heywood VH (1968) Helianthemum. In: Tutin TG, Heywood VH, Burges NA, Moore DM, Valentine DH, Walters SM, Webb DA (eds) Flora Europaea, vol. 2. Cambridge University Press, Cambridge, pp 286-291

Reitalu T, Helm A, Pärtel M, Bengtsson K, Gerhold P, Rosén E, Takkis K, Znamenskiy S, Prentice HC (2014) Determinants of finescale plant diversity in dry calcareous grasslands within the Baltic Sea region. Agric Ecosyst Environm 182:59-68. https://doi. org/10.1016/j.agee-2012.11.005

Rosén E (1982) Vegetation development and sheep grazing in limestone grasslands of south Öland. Acta Phytogeogr Suec 72:1-104

Sawa S (2002) Overexpression of the AtmybL2 gene represses trichome development in Arabidipsis. DNA Res 9:31-34

Schellmann S, Hülskamp M (2005) Epidermal differentiation: trichomes in Arabidopsis as a model system. Int J Developm Biol 49:579-584

Schwab B, Folkers U, Ilgenfritz H, Hulskamp M (2000) Trichome morphogenesis in Arabidopsis. Philos Trans Roy Soc London B 355:879-883

Scoville AG, Barnett LL, Bodbyl-Roels S, Kelly JK, Hileman C (2011) Differential regulation of a MYB transcription factor is correlated with transgenerational epigenetic inheritance of trichome density in Mimulus guttatus. New Phytol 191:251-263. https://doi.org/1 $0.1111 / \mathrm{j} .1469-8137.2011 .03656 . x$

Scriver CR, Waters PJ (1999) Monogenic traits are not that simple. Trends Genet 15:267-272

Soubani E (2010) Systematics, phylogeography and multiple origins of morphs in two species complexes belonging to Cistaceae, Helianthemum oelandicum and $H$. nummularium. PhD Thesis, Lund University, Lund

Soubani E, Hedrén M, Widén B (2014) Phylogeography of the European rock rose Helianthemum nummularium (Cistaceae): incongruent patterns of differentiation in plastid DNA and morphology. Bot J Linn Soc 176:311-331. https://doi.org/10.1111/boj.12209

Sterner R (1936a) Ekologiska iaktagelser över Helianthemum oelandicum (L.) Willd. Meddeland Göteborgs Bot Trädgård 11:183-208

Sterner R (1936b) Helianthemum oelandicum och dess anförvanter på Öland. Svenk Bot Tidskr 30:419-432

Suc JP (1984) Origin and evolution of the Mediterranean vegetation and climate in Europe. Nature 307:429-432

Svendsen JI, Alexanderson H, Astakhov VI, Demidov I, Dowdeswell JA, Funder S, Gataullin V, Henriksen M, Hjort C,
Houmark-Nielsen M, Hubberten HW, Ingólfsson Ó, Jakobsson M, Kjær KH, Larsen E, Lokrantz H, Lunkka JP, Lyså A, Mangerud J, Matiouchkov A, Murray A, Möller P, Niessen F, Nikolskaya O, Polyak L, Saarnisto M, Siegert C, Siegert MJ, Spielhagen RF, Stein R (2004) Late quaternary ice sheet history of northern Eurasia. Quatern Sci Rev 23:1229-1271. https://doi.org/10.1016/j. quascirev.2003.12.008

Törnblom G (1908) Iakttagelser öfver Helianthemum canum (L.) Baumg. och $H$, oelandicum (L.) Willd. På Ölands alvar. Svensk Bot Tidskr 2:32-37

Turesson G (1922) The genotypic response of the plant species to the habitat. Hereditas 3:211-350

Tyler T, Bengtsson F, Dahlberg CJ, Lönnell N, Hallingbäck T, Reitalu T (2018) Determinants of bryophyte species composition and diversity on the Great Alvar of Öland, Sweden. J Bryology 40:12-30. https://doi.org/10.1080/03736687.2017.1412387

Volkova PA, Schanzer IA, Soubani E, Meschersky IG, Widén B (2016) Phylogeography of the European rock rose Helianthemum nummularium s.l. (Cistaceae): western richness and eastern poverty. Pl Syst Evol 302:781-794. https://doi.org/10.1007/s0060 6-016-1299-1

Westerberg A (1992) The genetic bases of hairlessness in Silene dioica (Caryophyllaceae). Hereditas 117:287-291

Westerberg A, Nyberg AB (1995) Selective grazing of hairless Silene dioica plants by land gastropods. Oikos 73:289-298

Widén B (1980) Flowering strategies in Helianthemum oelandicum (Cistaceae) complex on Öland, Sweden. Bot Not 133:99-115

Widén B (1987) Establishment in populations of Helianthemum oelandicum with different flowering strategies. Int Bot Congr Abstract 306

Widén B (1988) Partitioning of variation in pubescence of a dwarf shrub, Helianthemum oelandicum. Acta Phytogeogr Suec 76:133-156

Widén B (2010) Cistaceae. In: Jonsell B, Karlsson T (eds) Flora Nordica 6. Swedish Museum of Natural History, Stockholm

Widén B (2015) Genetic basis of a key character in Helianthemum nummularium. Pl Syst Evol 301:1851-1862. https://doi. org/10.1007/s00606-015-1198-x

Widén B (2017) Inheritance of a hair character in Helianthmum oelandicun var. oelandicum and allele frequencies in natural populations. P1 Syst Evol 304:145-161. https://doi.org/10.1007/s0060 6-017-1457-0

Wood TE, Burke JM, Rieseberg LH (2005) Parallel genotypic adaptation: when evolution repeats itself. Genetica 123:157-170

Yol E, Uzun B (2011) Inheritance of number of capsules per leaf axil and hairiness on stem, leaf and capsules of sesame (Sesamum indicum L.). Austral J Crop Sci 5:78-81 